\title{
Quantification of water content and speciation in natural silicic glasses (phonolite, dacite, rhyolite) by confocal microRaman spectrometry
}

\author{
A. Di Muro ${ }^{\mathrm{a}}$, B. Villemant ${ }^{\mathrm{a}}$, G. Montagnac ${ }^{\underline{b}}$, B. Scaillet ${ }^{\underline{c}}$ and B. Reynard $\underline{\underline{b}}$ \\ a Laboratoire de Physique et Chimie des Systèmes Volcaniques, IPGP-Paris VI, \\ Paris, France \\ ${ }^{b}$ Laboratoire de Sciences de la Terre, Ecole Normale Supérieure, Lyon, France \\ 'Institut des Sciences de la Terre d'Orléans, CNRS-UO, Orléans, France
}

\section{Abstract}

The determination of total water content $\left(\mathrm{H}_{2} \mathrm{O}_{\mathrm{T}}\right.$ : $\left.0.1-10 \mathrm{wt} \%\right)$ and water speciation $\left(\mathrm{H}_{2} \mathrm{O}_{\text {molecular }} / \mathrm{OH}\right)$ in volcanic products by confocal microRaman spectrometry are discussed for alkaline (phonolite) and calcalkaline (dacite and rhyolite) silicic glasses. Shape and spectral distribution of the total water band $\left(\mathrm{H}_{2} \mathrm{O}_{\mathrm{T}}\right)$ at $\sim 3550 \mathrm{~cm}^{-1}$ show systematic evolution with glass $\mathrm{H}_{2} \mathrm{O}_{\mathrm{T}}$, water speciation and $\mathrm{NBO} / \mathrm{T}$. In the studied set of silicic samples, calibrations based on internal normalization of the $\mathrm{H}_{2} \mathrm{O}_{T}$ band to a band related to vibration of aluminosilicate network (TOT) at $\approx 490 \mathrm{~cm}^{-1}$ vary with glass peraluminosity. An external calibration procedure using well-characterized glass standards is less composition-dependent and provides excellent linear correlation between total dissolved water content and height or area of the $\mathrm{H}_{2} \mathrm{O}_{T}$ Raman band. Accuracy of deconvolution procedure of the $\mathrm{H}_{2} \mathrm{O}_{T}$ band to quantify water speciation in water-rich and depolymerized glasses depends on the strength of $\mathrm{OH}$ hydrogen bonding. System confocal performance, scattering from embedding medium and glass microcrystallinity have a crucial influence on accuracy of Raman analyses of water content in glass-bearing rocks and melt inclusions in crystals.

\section{Introduction}

Laser Raman spectroscopy has been extensively used for structural studies of hydrous natural and synthetic silicate glasses (e.g., Mysen et al., 1980, McMillan and Remmele, 1986, Mysen and Virgo, 1986b, Mysen, 1990, Zotov and Keppler, 1998 and Zotov, 2003) and for chemical and physical characterization of fluid inclusions (e.g., Dubessy et al., 1989, Chou et al., 1990, Wopenka et al., 1990, Pasteris et al., 1996 and Chen et al., 2004). Recently, new Raman analytical routines have been proposed for the quantitative analysis of total water content $\left(\mathrm{H}_{2} \mathrm{O}_{\mathrm{T}}\right)$ and speciation $\left(\mathrm{H}_{2} \mathrm{O}_{\mathrm{m}}\right.$ molecular/hydroxyl $\left.\mathrm{OH}\right)$ in natural and synthetic aluminosilicate glasses (Thomas, 2000, Thomas, 2002, Chabiron et al., 2004 and Arias et al., 2006). These studies have demonstrated the high accuracy and repeatability of Raman spectrometric analyses of water in glass chips or glass inclusions in the $\mathrm{H}_{2} \mathrm{O}_{\text {T }}$ range $0.1-20 w t \%$.

The development of quantitative Raman routines represents an important improvement for the microanalysis of water in geomaterials mostly because of its very small analytical spot $(1-2 \mu \mathrm{m})$ and the easy sample preparation that just requires polishing. In particular, petrological and volcanological studies can 
substantially benefit from establishment of Raman routines applicable to natural glasses. In practice, the microRaman technique potentially allows accessing to all the glass inclusion populations in a given sample or to small glass volumes in highly crystallized products. The technique does not require exposing glass inclusions if embedded in transparent crystals and allows preserving the mutual spatial relationships between the different phases. Furthermore, matrix glasses, glass and fluid inclusions can be analysed with the same instrument in a single analytical session. This analytical approach permits to collect a statistically representative database necessary for studying the volatile phase in a magma reservoir (Cioni, 2000) and modelling processes as magma degassing (Villemant et al., 2003), magma crystallization (Scaillet and Evans, 1999), evolution of eruptive dynamics (Di Muro et al., 2004), pyroclastic-rock thermal history (Wallace et al., 2003) or provenance (Arias et al., 2006) and magma-water interaction (Slejko et al., 2004).

Previous quantitative microRaman studies of water in natural glasses have dealt mostly with Si-rich, $\mathrm{CaO}, \mathrm{MgO}$ and $\mathrm{FeO}-$ poor $(\mathrm{CaO}$ and $\mathrm{FeO}<1 \mathrm{wt} \%$; $\mathrm{MgO}<0.1 \mathrm{wt} \%$ ) aluminosilicate systems of rhyolite, pegmatite and albite composition (Thomas, 2000, Chabiron et al., 2004 and Arias et al., 2006). Preliminary researches of Thomas (2002) suggest that different calibrations should be adopted for rhyolite and basalt glasses. In this paper, we test a range of microRaman routines to determine water contents $\left(\mathrm{H}_{2} \mathrm{O}_{\mathrm{T}}\right.$ : $\left.<0.1-10 \mathrm{wt} \%\right)$ and speciations at room temperature in a set of silicic volcanic glasses (phonolites, dacite, rhyolites) covering a wide range of major and volatile $\left(\mathrm{H}_{2} \mathrm{O}, \mathrm{F}, \mathrm{Cl}, \mathrm{S}\right)$ element compositions (Table 1). In particular, we discuss (1) advantages and drawbacks of external vs. internal calibrations and (2) composition-dependence of the different Raman routines. We compare our Raman data with the large dataset of FTIR data on water speciation as a function of $\mathrm{H}_{2} \mathrm{O}$ content available for analogous glass compositions (Newman et al., 1986, Newman et al., 1988, Silver et al., 1990, Kohn et al., 1992, Pandya et al., 1992, Nowak and Behrens, 1995, Zhang et al., 1995, Carroll and Blank, 1997, Sowerby and Keppler, 1999, Nowak and Behrens, 2001, Ohlhorst et al., 2001, Schmidt et al., 2001 and Whittington et al., 2001) and with some glass inclusions previously measured by FTIR (Cioni, 2000).

We focus on the reliability of Raman spectroscopy for the quantitative analysis of total water content and speciation in chemically complex glasses with total iron $\left(\mathrm{FeO}_{\mathrm{T}}\right)$ up to $4.5 \mathrm{wt} \%$. This work represents clearly only a first step in assessing the dependence of this technique on natural glass composition. 
Table 1. : Conditions of hydration and cooling and electron microprobe analyses of standards glasses (phonolite, dacite, rhyolite) used to define Raman calibration lines in this study

\begin{tabular}{|c|c|c|c|c|c|c|c|c|}
\hline Sample: & 79AD & 472AD & PIN & GB15 & M77 & SMN49 & LIP & LGM \\
\hline $\begin{array}{l}\text { Provenan } \\
\text { ce: }\end{array}$ & $\begin{array}{l}\text { Pomp } \\
\text { ei } 79 \\
\text { AD }\end{array}$ & $\begin{array}{l}\text { Pollen } \\
\text { a } 472 \\
\text { AD }\end{array}$ & $\begin{array}{l}\text { Pinat } \\
\text { ubo } \\
1991\end{array}$ & Himalaya & Mexico & $\begin{array}{l}\text { Naivas } \\
\text { ha }\end{array}$ & Lipari & $\begin{array}{l}\text { Little } \\
\text { Glass Mt. }\end{array}$ \\
\hline $\begin{array}{l}\text { Referenc } \\
\text { e: }\end{array}$ & 1 & 1 & 2 & 3 & $\begin{array}{l}\text { This } \\
\text { paper }\end{array}$ & 4 & $\begin{array}{l}\text { This } \\
\text { paper }\end{array}$ & $\begin{array}{l}\text { This } \\
\text { paper }\end{array}$ \\
\hline $\begin{array}{l}\text { Composi } \\
\text { tion: }\end{array}$ & $\begin{array}{l}\text { Low- } \\
\text { Ca } \\
\text { phono } \\
\text { lite }\end{array}$ & $\begin{array}{l}\text { High } \\
\mathrm{Ca} \\
\text { phono } \\
\text { lite }\end{array}$ & Dacite & $\begin{array}{l}\text { Peralumi } \\
\text { nous } \\
\text { rhyolite }\end{array}$ & $\begin{array}{l}\text { Metalumi } \\
\text { nous } \\
\text { rhyolite }\end{array}$ & $\begin{array}{l}\text { Peralka } \\
\text { line } \\
\text { rhyolite }\end{array}$ & $\begin{array}{l}\text { Metalumi } \\
\text { nous } \\
\text { rhyolite }\end{array}$ & $\begin{array}{l}\text { Metalumi } \\
\text { nous } \\
\text { rhyolite }\end{array}$ \\
\hline $\begin{array}{l}\mathrm{H}_{2} \mathrm{O} \\
\text { (range } \\
\text { wt\%) }\end{array}$ & $0-6.80$ & $0-6.70$ & $\begin{array}{l}0- \\
6.36\end{array}$ & $6.56-9.46$ & 3.50 & 2.50 & 0.52 & 0.23 \\
\hline $\mathrm{H}_{2} \mathrm{O} 1 \sigma \%$ & $<2$ & $<2$ & $<2$ & $<5$ & $<5$ & $<2$ & $<5$ & $<5$ \\
\hline $\begin{array}{l}\text { Techniqu } \\
\text { e }\end{array}$ & $\mathrm{KFT}$ & $\mathrm{KFT}$ & $\mathrm{KFT}$ & SIMS & $\begin{array}{l}\text { Manometr } \\
\text { y }\end{array}$ & $\mathrm{KFT}$ & $\begin{array}{l}\text { Manometr } \\
\text { y }\end{array}$ & $\begin{array}{l}\text { Manometr } \\
\text { y }\end{array}$ \\
\hline $\mathrm{SiO}_{2}$ & 56.09 & 51.36 & 64.81 & 74.51 & 76.14 & 74.38 & 74.71 & 73.37 \\
\hline $\mathrm{TiO}_{2}$ & 0.19 & 0.48 & 0.51 & 0.09 & 0.13 & 0.17 & 0.09 & 0.22 \\
\hline $\mathrm{Al}_{2} \mathrm{O}_{3}$ & 22.02 & 21.63 & 16.94 & 15.45 & 12.91 & 10.92 & 13.35 & 14.03 \\
\hline $\mathrm{FeO}$ & 2.26 & 4.54 & 4.04 & 0.64 & 0.93 & 4.00 & 1.57 & 1.94 \\
\hline $\mathrm{MnO}$ & nd & nd & 0.09 & nd & 0.03 & 0.06 & 0.08 & 0.03 \\
\hline $\mathrm{MgO}$ & 0.18 & 0.74 & 2.42 & 0.13 & 0.12 & 0.00 & 0.04 & 0.31 \\
\hline $\mathrm{CaO}$ & 2.80 & 5.90 & 4.92 & 0.52 & 0.92 & 0.29 & 0.77 & 1.29 \\
\hline $\mathrm{Na}_{2} \mathrm{O}$ & 6.22 & 5.92 & 4.72 & 4.44 & 2.98 & 5.83 & 3.89 & 4.28 \\
\hline $\mathrm{K}_{2} \mathrm{O}$ & 10.25 & 9.42 & 1.55 & 4.23 & 5.81 & 4.35 & 5.48 & 4.53 \\
\hline $\mathrm{P}_{2} \mathrm{O}_{5}$ & nd & nd & nd & nd & 0.01 & nd & 0.03 & nd \\
\hline $\mathrm{Cl}$ (ppm) & nd & nd & 100 & nd & 516 & 4940 & 2998 & 448 \\
\hline $\mathrm{F}(\mathrm{ppm})$ & 1200 & 700 & nd & nd & 274 & 9900 & 1290 & 301 \\
\hline$S(p p m)$ & nd & nd & 67 & nd & 30 & nd & 10 & 19 \\
\hline $\begin{array}{l}\mathrm{NBO} / \mathrm{T} \\
\text { (range) }\end{array}$ & $\begin{array}{l}0.08- \\
0.63\end{array}$ & $\begin{array}{l}0.19- \\
0.76\end{array}$ & $\begin{array}{l}0.13- \\
0.62\end{array}$ & $0.44-0.65$ & 0.26 & 0.26 & 0.05 & 0.04 \\
\hline $\mathrm{A} / \mathrm{CNK}^{\mathrm{a}}$ & 0.83 & 0.71 & 0.92 & 1.21 & 1.00 & 0.74 & 0.97 & 0.98 \\
\hline
\end{tabular}




\begin{tabular}{|c|c|c|c|c|c|c|c|c|}
\hline Sample: & 79AD & 472AD & PIN & GB15 & M77 & SMN49 & LIP & LGM \\
\hline $\begin{array}{l}\text { Provenan } \\
\text { ce: }\end{array}$ & $\begin{array}{l}\text { Pomp } \\
\text { ei } 79 \\
\text { AD }\end{array}$ & $\begin{array}{l}\text { Pollen } \\
\text { a } 472 \\
\text { AD }\end{array}$ & $\begin{array}{l}\text { Pinat } \\
\text { ubo } \\
1991\end{array}$ & Himalaya & Mexico & $\begin{array}{l}\text { Naivas } \\
\text { ha }\end{array}$ & Lipari & $\begin{array}{l}\text { Little } \\
\text { Glass Mt. }\end{array}$ \\
\hline $\begin{array}{l}\text { Referenc } \\
\text { e: }\end{array}$ & 1 & 1 & 2 & 3 & $\begin{array}{l}\text { This } \\
\text { paper }\end{array}$ & 4 & $\begin{array}{l}\text { This } \\
\text { paper }\end{array}$ & $\begin{array}{l}\text { This } \\
\text { paper }\end{array}$ \\
\hline $\begin{array}{l}\text { Composi } \\
\text { tion: }\end{array}$ & $\begin{array}{l}\text { Low- } \\
\text { Ca } \\
\text { phono } \\
\text { lite }\end{array}$ & $\begin{array}{l}\text { High } \\
\text { Ca } \\
\text { phono } \\
\text { lite }\end{array}$ & Dacite & $\begin{array}{l}\text { Peralumi } \\
\text { nous } \\
\text { rhyolite }\end{array}$ & $\begin{array}{l}\text { Metalumi } \\
\text { nous } \\
\text { rhyolite }\end{array}$ & $\begin{array}{l}\text { Peralka } \\
\text { line } \\
\text { rhyolite }\end{array}$ & $\begin{array}{l}\text { Metalumi } \\
\text { nous } \\
\text { rhyolite }\end{array}$ & $\begin{array}{l}\text { Metalumi } \\
\text { nous } \\
\text { rhyolite }\end{array}$ \\
\hline $\begin{array}{l}\mathrm{Na}_{2} \mathrm{O}+\mathrm{K}_{2} \\
\mathrm{O}\end{array}$ & 16.4 & 15.3 & 6.3 & 8.7 & 8.8 & 10.0 & 9.4 & 8.8 \\
\hline $\mathrm{K}_{2} \mathrm{O} / \mathrm{Na}_{2} \mathrm{O}$ & 1.6 & 1.6 & 0.3 & 1.0 & 1.9 & 0.7 & 1.4 & 1.1 \\
\hline \multicolumn{9}{|c|}{ Glass synthesis conditions } \\
\hline$P$ (bar) & 2000 & 2000 & 3000 & 4000 & $<5$ & 2000 & $<5$ & $<5$ \\
\hline$T\left({ }^{\circ} \mathrm{C}\right)$ & 1200 & 1200 & 1400 & $803-720$ & $?$ & 830 & $?$ & $?$ \\
\hline Quench & Drop & Drop & $\begin{array}{l}\text { Isobari } \\
\text { c }\end{array}$ & Isobaric & "Isobaric" & Drop & "Isobaric" & "Isobaric" \\
\hline $\begin{array}{l}\text { Quench } \\
\text { rate }\left({ }^{\circ} \mathrm{C} / \mathrm{s}\right)\end{array}$ & $\begin{array}{l}100- \\
200\end{array}$ & $\begin{array}{l}100- \\
200\end{array}$ & $\begin{array}{l}2.0- \\
3.0\end{array}$ & $2.0-3.0$ & $<0.01$ & $\begin{array}{l}100- \\
200\end{array}$ & $<0.01$ & $<0.01$ \\
\hline
\end{tabular}

References: (1) Scaillet and Pichavant, 2004; (2) Scaillet and Evans (1999); (3) Scaillet et al. (1995); (4) Scaillet and Mcdonald (2001). Typical analytical errors of EPMA analyses were $<1 \%$ for $\mathrm{SiO}_{2}$, $\mathrm{Al}_{2} \mathrm{O}_{3},<5 \%$ for $\mathrm{CaO}, \mathrm{Na}_{2} \mathrm{O}, \mathrm{K}_{2} \mathrm{O}, \mathrm{MgO}, \mathrm{FeO}$ and $<10 \%$ for $\mathrm{TiO}_{2}, \mathrm{MnO}, \mathrm{F}, \mathrm{Cl}$. Total water content in glass samples has been determined by Karl-Fischer titration (KFT), secondary ion mass spectrometry (SIMS) and hydrogen manometry (Michel and Villemant, 2003). NBO/T, number of non-bridging oxygens per tetrahedrally coordinated cation $\left(\mathrm{T}: \mathrm{Si}, \mathrm{Al}, \mathrm{Fe}^{3+}, \mathrm{P}\right)$. NBO/T have been calculated by assuming that (1) all $\mathrm{H}_{2} \mathrm{O}$ is in the form $\mathrm{H}_{2} \mathrm{O}_{\mathrm{m}}$ or $\mathrm{T}-\mathrm{OH}$, (2) alkali-balanced $\mathrm{Al}$ is in tetrahedral coordination and excess $\mathrm{Al}$ acts as a network modifier, (3) half of total iron is in the form $\mathrm{Fe}^{3+}$. Assumptions 1 and 3 are the strongest. They could mostly affect the estimation of NBO/T in alkaliearth- and iron-rich glasses such as the Pollena phonolite, but probably only moderately because they operate in opposite directions (increase in modifier-bonded $\mathrm{M}-\mathrm{OH}$ and decrease in $\left(\mathrm{Fe}^{3+}\right)^{\mathrm{VV}}$ are expected to produce opposite variations in NBO).

nd, not determined.

${ }^{a}$ Molar $\mathrm{Al}_{2} \mathrm{O}_{3} /\left(\mathrm{CaO}+\mathrm{Na}_{2} \mathrm{O}+\mathrm{K}_{2} \mathrm{O}\right)$. 


\section{Glass samples}

In order to investigate the influence of glass composition and structure on microRaman calibrations we selected a set of rhyolite, dacite and phonolite hydrous glasses covering a large range of NBO/T (0.04-0.80) (Table 1). We calibrated microRaman routines for determination of total water contents on naturally hydrous (metaluminous rhyolites: obsidians LIP and LGM; rhyolite M77; glass inclusions QMD) and hydrated glasses (peraluminous rhyolite set: GB15; peralkaline rhyolite glass: SMN49; phonolite sets: 79AD and 472AD; dacite set: PIN) (Table 1 and Table 2).

Table 2. : Composition of glass inclusions analysed by microRaman spectrometry in this study

\begin{tabular}{|c|c|c|c|c|c|c|c|c|c|c|c|c|c|}
\hline $\begin{array}{l}\text { Sampl } \\
\text { e: }\end{array}$ & $\begin{array}{l}\text { Sh1 } \\
12\end{array}$ & $\begin{array}{l}\text { Sh2 } \\
41\end{array}$ & $\begin{array}{l}\text { Sh2 } \\
61\end{array}$ & $\begin{array}{l}\text { Sh2 } \\
52\end{array}$ & $\begin{array}{l}\text { Sh2 } \\
11\end{array}$ & P5A & $\begin{array}{l}\text { P2C } \\
1\end{array}$ & $\begin{array}{l}\mathrm{P} 2 \mathrm{C} \\
2\end{array}$ & T2D & $\begin{array}{l}\text { QM } \\
\text { D }\end{array}$ & $\begin{array}{l}\text { MI } \\
1- \\
\mathrm{cx} \\
2\end{array}$ & $\begin{array}{l}\text { MI } \\
4- \\
\text { CX } \\
9\end{array}$ & $\begin{array}{l}\text { MI4 } \\
- \\
\text { cx9 } \\
\text { MI1 } \\
-\end{array}$ \\
\hline $\begin{array}{l}\text { Prove } \\
\text { nance: }\end{array}$ & $\begin{array}{l}\text { Laac } \\
\text { her } \\
\text { See }\end{array}$ & $\begin{array}{l}\text { Laac } \\
\text { her } \\
\text { See }\end{array}$ & $\begin{array}{l}\text { Laac } \\
\text { her } \\
\text { See }\end{array}$ & $\begin{array}{l}\text { Laac } \\
\text { her } \\
\text { See }\end{array}$ & $\begin{array}{l}\text { Laa } \\
\text { che } \\
r \\
\text { See }\end{array}$ & $\begin{array}{l}\text { Pom } \\
\text { pei } \\
79 \\
\text { AD }\end{array}$ & $\begin{array}{l}\text { Pom } \\
\text { pei } \\
79 \\
\text { AD }\end{array}$ & $\begin{array}{l}\text { Pom } \\
\text { pei } \\
79 \\
\text { AD }\end{array}$ & $\begin{array}{l}\text { Pom } \\
\text { pei } \\
79 \\
\text { AD }\end{array}$ & $\begin{array}{l}\text { Mt. } \\
\text { Dor } \\
\text { e }\end{array}$ & $\begin{array}{l}\text { Pic } \\
0\end{array}$ & $\begin{array}{l}\text { Pic } \\
0\end{array}$ & $\begin{array}{l}\text { Pic } \\
0\end{array}$ \\
\hline $\begin{array}{l}\text { Refere } \\
\text { nce: }\end{array}$ & 1 & 1 & 1 & 1 & 1 & 2 & 2 & 2 & 2 & 3 & $\begin{array}{l}\text { Thi } \\
\text { s } \\
\text { pa } \\
\text { pe } \\
\text { r }\end{array}$ & $\begin{array}{l}\text { Thi } \\
\text { s } \\
\text { pa } \\
\text { pe } \\
\text { r }\end{array}$ & $\begin{array}{l}\text { Thi } \\
\text { s } \\
\text { pap } \\
\text { er }\end{array}$ \\
\hline $\begin{array}{l}\text { Comp } \\
\text { ositio } \\
\text { n: }\end{array}$ & $\begin{array}{l}\text { Pho } \\
\text { nolit } \\
\text { e }\end{array}$ & $\begin{array}{l}\text { Pho } \\
\text { nolit } \\
\text { e }\end{array}$ & $\begin{array}{l}\text { Pho } \\
\text { nolit } \\
\text { e }\end{array}$ & $\begin{array}{l}\text { Pho } \\
\text { nolit } \\
\text { e }\end{array}$ & $\begin{array}{l}\text { Tra } \\
\text { chyt } \\
\text { e }\end{array}$ & $\begin{array}{l}\text { Pho } \\
\text { nolit } \\
\text { e }\end{array}$ & $\begin{array}{l}\text { Pho } \\
\text { nolit } \\
\text { e }\end{array}$ & $\begin{array}{l}\text { Pho } \\
\text { nolit } \\
\text { e }\end{array}$ & $\begin{array}{l}\text { Pho } \\
\text { nolit } \\
\text { e }\end{array}$ & $\begin{array}{l}\text { Rhy } \\
\text { olit } \\
\text { e }\end{array}$ & $\begin{array}{l}\text { Da } \\
\text { cit } \\
e\end{array}$ & $\begin{array}{l}\text { Da } \\
\text { cit } \\
e\end{array}$ & $\begin{array}{l}\text { Dac } \\
\text { ite }\end{array}$ \\
\hline Host & $\begin{array}{l}\text { Hau } \\
\text { yne }\end{array}$ & $\begin{array}{l}\text { Hau } \\
\text { yne }\end{array}$ & $\begin{array}{l}\text { Mag } \\
\text { netit } \\
\text { e }\end{array}$ & $\begin{array}{l}\text { Mag } \\
\text { netit } \\
\mathrm{e}\end{array}$ & $\mathrm{cpx}$ & $\begin{array}{l}\text { Leuc } \\
\text { ite }\end{array}$ & $\begin{array}{l}\text { Leuc } \\
\text { ite }\end{array}$ & $\begin{array}{l}\text { Leuc } \\
\text { ite }\end{array}$ & $\begin{array}{l}\text { Sani } \\
\text { dine }\end{array}$ & $\begin{array}{l}\text { Qua } \\
\text { rtz }\end{array}$ & $\begin{array}{l}o p \\
x\end{array}$ & $\begin{array}{l}\mathrm{cp} \\
\mathbf{x}\end{array}$ & $c p x$ \\
\hline $\begin{array}{l}\mathrm{H}_{2} \mathrm{O} \\
\text { (wt\%) }\end{array}$ & 1.52 & 1.55 & 3.38 & 2.59 & 4.12 & 0.66 & 1.08 & 1.35 & 3.83 & 5.00 & $\begin{array}{l}3.1 \\
7\end{array}$ & $\begin{array}{l}3.6 \\
0\end{array}$ & $\begin{array}{l}4.7 \\
7\end{array}$ \\
\hline $\begin{array}{l}1 \sigma \\
(w t \%)\end{array}$ & 0.08 & 0.08 & 0.17 & 0.13 & 0.21 & 0.10 & 0.04 & 0.12 & 0.05 & 0.10 & $\begin{array}{l}0.6 \\
4\end{array}$ & $\begin{array}{l}0.5 \\
0\end{array}$ & $\begin{array}{l}0.5 \\
0\end{array}$ \\
\hline $\begin{array}{l}\text { Techni } \\
\text { que }\end{array}$ & $\begin{array}{l}\text { SIM } \\
\text { S }\end{array}$ & $\begin{array}{l}\text { SIM } \\
\text { S }\end{array}$ & $\begin{array}{l}\text { SIM } \\
\text { S }\end{array}$ & $\begin{array}{l}\text { SIM } \\
\text { S }\end{array}$ & $\begin{array}{l}\text { SIM } \\
\text { S }\end{array}$ & FTIR & FTIR & FTIR & FTIR & $\begin{array}{l}\mathrm{FTI} \\
\mathrm{R}\end{array}$ & $\begin{array}{l}\text { EP } \\
M A\end{array}$ & $\begin{array}{l}\text { EP } \\
M A\end{array}$ & $\begin{array}{l}\text { EP } \\
\text { MA }\end{array}$ \\
\hline $\mathrm{SiO}_{2}$ & $\begin{array}{l}59.9 \\
5\end{array}$ & $\begin{array}{l}60.1 \\
9\end{array}$ & $\begin{array}{l}60.4 \\
6\end{array}$ & $\begin{array}{l}60.3 \\
5\end{array}$ & $\begin{array}{l}63.2 \\
4\end{array}$ & $\begin{array}{l}56.2 \\
3\end{array}$ & $\begin{array}{l}55.0 \\
5\end{array}$ & $\begin{array}{l}55.2 \\
4\end{array}$ & $\begin{array}{l}58.6 \\
4\end{array}$ & $\begin{array}{l}77.3 \\
7\end{array}$ & $\begin{array}{l}63 . \\
47\end{array}$ & $\begin{array}{l}67 . \\
59\end{array}$ & $\begin{array}{l}68 . \\
66\end{array}$ \\
\hline $\mathrm{TiO}_{2}$ & 0.6 & 0.6 & 0.8 & 0.8 & 0.6 & 0.16 & 0.17 & 0.18 & 0.08 & 0.12 & $\begin{array}{l}0.9 \\
2\end{array}$ & $\begin{array}{l}0.9 \\
3\end{array}$ & $\begin{array}{l}0.7 \\
8\end{array}$ \\
\hline $\mathrm{Al}_{2} \mathrm{O}_{3}$ & $\begin{array}{l}19.5 \\
8\end{array}$ & $\begin{array}{l}19.0 \\
2\end{array}$ & $\begin{array}{l}20.4 \\
9\end{array}$ & $\begin{array}{l}20.5 \\
3\end{array}$ & $\begin{array}{l}20.1 \\
4\end{array}$ & $\begin{array}{l}23.4 \\
7\end{array}$ & $\begin{array}{l}23.4 \\
1\end{array}$ & $\begin{array}{l}23.5 \\
5\end{array}$ & $\begin{array}{l}21.8 \\
7\end{array}$ & $\begin{array}{l}12.4 \\
5\end{array}$ & $\begin{array}{l}17 . \\
57\end{array}$ & $\begin{array}{l}20 . \\
11\end{array}$ & $\begin{array}{l}19 . \\
22\end{array}$ \\
\hline
\end{tabular}




\begin{tabular}{|c|c|c|c|c|c|c|c|c|c|c|c|c|c|}
\hline $\begin{array}{l}\text { Sampl } \\
\text { e: }\end{array}$ & $\begin{array}{l}\text { Sh1 } \\
12\end{array}$ & $\begin{array}{l}\text { Sh2 } \\
41\end{array}$ & $\begin{array}{l}\text { Sh2 } \\
61\end{array}$ & $\begin{array}{l}\text { Sh2 } \\
52\end{array}$ & $\begin{array}{l}\text { Sh2 } \\
11\end{array}$ & P5A & $\begin{array}{l}\text { P2C } \\
1\end{array}$ & $\begin{array}{l}\text { P2C } \\
2\end{array}$ & T2D & $\begin{array}{l}\text { QM } \\
\text { D }\end{array}$ & $\begin{array}{l}\text { MI } \\
1- \\
\mathrm{cx} \\
2\end{array}$ & $\begin{array}{l}\text { MI } \\
4- \\
\text { CX } \\
9\end{array}$ & $\begin{array}{l}\text { M14 } \\
- \\
\text { cx9 } \\
\text { MI1 } \\
-\end{array}$ \\
\hline $\begin{array}{l}\text { Prove } \\
\text { nance: }\end{array}$ & $\begin{array}{l}\text { Laac } \\
\text { her } \\
\text { See }\end{array}$ & $\begin{array}{l}\text { Laac } \\
\text { her } \\
\text { See }\end{array}$ & $\begin{array}{l}\text { Laac } \\
\text { her } \\
\text { See }\end{array}$ & $\begin{array}{l}\text { Laac } \\
\text { her } \\
\text { See }\end{array}$ & $\begin{array}{l}\text { Laa } \\
\text { che } \\
r \\
\text { See }\end{array}$ & $\begin{array}{l}\text { Pom } \\
\text { pei } \\
79 \\
\text { AD }\end{array}$ & $\begin{array}{l}\text { Pom } \\
\text { pei } \\
79 \\
\text { AD }\end{array}$ & $\begin{array}{l}\text { Pom } \\
\text { pei } \\
79 \\
\text { AD }\end{array}$ & $\begin{array}{l}\text { Pom } \\
\text { pei } \\
79 \\
\text { AD }\end{array}$ & $\begin{array}{l}\text { Mt. } \\
\text { Dor } \\
\text { e }\end{array}$ & $\begin{array}{l}\text { Pic } \\
0\end{array}$ & $\begin{array}{l}\text { Pic } \\
0\end{array}$ & $\begin{array}{l}\text { Pic } \\
0\end{array}$ \\
\hline $\begin{array}{l}\text { Refere } \\
\text { nce: }\end{array}$ & 1 & 1 & 1 & 1 & 1 & 2 & 2 & 2 & 2 & 3 & $\begin{array}{l}\text { Thi } \\
\text { s } \\
\text { pa } \\
\text { pe } \\
\text { r }\end{array}$ & $\begin{array}{l}\text { Thi } \\
\text { s } \\
\text { pa } \\
\text { pe } \\
\text { r }\end{array}$ & $\begin{array}{l}\text { Thi } \\
\text { s } \\
\text { pap } \\
\text { er }\end{array}$ \\
\hline $\begin{array}{l}\text { Comp } \\
\text { ositio } \\
\text { n: }\end{array}$ & $\begin{array}{l}\text { Pho } \\
\text { nolit } \\
\text { e }\end{array}$ & $\begin{array}{l}\text { Pho } \\
\text { nolit } \\
\text { e }\end{array}$ & $\begin{array}{l}\text { Pho } \\
\text { nolit } \\
\text { e }\end{array}$ & $\begin{array}{l}\text { Pho } \\
\text { nolit } \\
\text { e }\end{array}$ & $\begin{array}{l}\text { Tra } \\
\text { chyt } \\
\text { e }\end{array}$ & $\begin{array}{l}\text { Pho } \\
\text { nolit } \\
\text { e }\end{array}$ & $\begin{array}{l}\text { Pho } \\
\text { nolit } \\
\text { e }\end{array}$ & $\begin{array}{l}\text { Pho } \\
\text { nolit } \\
\text { e }\end{array}$ & $\begin{array}{l}\text { Pho } \\
\text { nolit } \\
\text { e }\end{array}$ & $\begin{array}{l}\text { Rhy } \\
\text { olit } \\
\text { e }\end{array}$ & $\begin{array}{l}\text { Da } \\
\text { cit } \\
\text { e }\end{array}$ & $\begin{array}{l}\text { Da } \\
\text { cit } \\
\text { e }\end{array}$ & $\begin{array}{l}\text { Dac } \\
\text { ite }\end{array}$ \\
\hline $\mathrm{FeO}$ & 2.09 & 2.23 & 1.98 & 2.08 & 1.61 & 1.80 & 2.28 & 2.10 & 0.99 & 0.78 & $\begin{array}{l}4.9 \\
4\end{array}$ & $\begin{array}{l}2.3 \\
1\end{array}$ & $\begin{array}{l}1.6 \\
7\end{array}$ \\
\hline $\mathrm{MnO}$ & 0.17 & 0.16 & 0.06 & 0.06 & 0.14 & 0.14 & 0.12 & 0.18 & 0.08 & 0.04 & $\begin{array}{l}0.0 \\
9\end{array}$ & $\begin{array}{l}0.0 \\
4\end{array}$ & $\begin{array}{l}0.0 \\
6\end{array}$ \\
\hline $\mathrm{MgO}$ & 0.26 & 0.26 & 0.29 & 0.31 & 0.06 & 0.06 & 0.05 & 0.05 & 0.02 & 0.04 & $\begin{array}{l}1.5 \\
7\end{array}$ & $\begin{array}{l}0.6 \\
2\end{array}$ & $\begin{array}{l}0.3 \\
2\end{array}$ \\
\hline $\mathrm{CaO}$ & 2.57 & 3.11 & 2.68 & 2.65 & 1.15 & 2.43 & 2.66 & 2.46 & 1.44 & 0.29 & $\begin{array}{l}4.8 \\
3\end{array}$ & $\begin{array}{l}4.5 \\
0\end{array}$ & $\begin{array}{l}3.4 \\
7\end{array}$ \\
\hline $\mathrm{Na}_{2} \mathrm{O}$ & 4.65 & 4.24 & 5.31 & 5.15 & 4.64 & $\begin{array}{l}10.6 \\
9\end{array}$ & $\begin{array}{l}10.0 \\
8\end{array}$ & $\begin{array}{l}10.1 \\
9\end{array}$ & 5.32 & 4.17 & $\begin{array}{l}4.2 \\
7\end{array}$ & $\begin{array}{l}1.9 \\
2\end{array}$ & $\begin{array}{l}2.9 \\
4\end{array}$ \\
\hline $\mathrm{K}_{2} \mathrm{O}$ & $\begin{array}{l}10.0 \\
4\end{array}$ & $\begin{array}{l}10.1 \\
2\end{array}$ & 7.81 & 7.92 & 8.29 & 5.01 & 6.17 & 6.05 & $\begin{array}{l}11.5 \\
5\end{array}$ & 4.73 & $\begin{array}{l}2.3 \\
4\end{array}$ & $\begin{array}{l}1.9 \\
8\end{array}$ & $\begin{array}{l}2.8 \\
7\end{array}$ \\
\hline $\mathrm{P}_{2} \mathrm{O}_{5}$ & 0.08 & 0.10 & 0.15 & 0.15 & 0.14 & bdl & bdl & bdl & bdl & nd & nd & nd & nd \\
\hline $\begin{array}{l}\mathrm{Cl} \\
\text { (ppm) }\end{array}$ & 1417 & 1729 & 2169 & 1969 & $\begin{array}{l}227 \\
0\end{array}$ & 6240 & 9180 & 8490 & 3780 & $\begin{array}{l}322 \\
3\end{array}$ & $\begin{array}{l}12 \\
60\end{array}$ & $\begin{array}{l}13 \\
90\end{array}$ & $\begin{array}{l}140 \\
0\end{array}$ \\
\hline $\begin{array}{l}\mathrm{F} \\
(\mathrm{ppm})\end{array}$ & 4545 & 4700 & 1292 & 1221 & 856 & 5500 & 4800 & 7100 & 3400 & nd & bdl & $\begin{array}{l}14 \\
30\end{array}$ & bdl \\
\hline $\begin{array}{l}\text { S } \\
\text { (ppm) }\end{array}$ & 96 & 160 & 710 & 628 & 298 & bdl & bdl & 96 & bdl & nd & $\begin{array}{l}14 \\
58\end{array}$ & $\begin{array}{l}21 \\
96\end{array}$ & $\begin{array}{l}132 \\
8\end{array}$ \\
\hline $\mathrm{A} / \mathrm{CNK}$ & 0.84 & 0.81 & 0.93 & 0.94 & 1.08 & 0.86 & 0.83 & 0.85 & 0.92 & 1.00 & $\begin{array}{l}0.9 \\
6\end{array}$ & $\begin{array}{l}1.4 \\
9\end{array}$ & $\begin{array}{l}1.3 \\
5\end{array}$ \\
\hline $\begin{array}{l}\mathrm{Na}_{2} \mathrm{O} \\
+\mathrm{K} 2 \mathrm{O}\end{array}$ & 14.7 & 14.4 & 13.1 & 13.1 & 12.9 & 15.7 & 16.2 & 16.2 & 16.9 & 8.9 & 6.6 & 3.9 & 5.8 \\
\hline $\begin{array}{l}\mathrm{K}_{2} \mathrm{O} / \mathrm{N} \\
\mathrm{a}_{2} \mathrm{O}\end{array}$ & 2.2 & 2.4 & 1.5 & 1.5 & 1.8 & 0.5 & 0.6 & 0.6 & 2.2 & 1.1 & 0.5 & 1.0 & 1.0 \\
\hline
\end{tabular}


Glass inclusions were previously analysed for water by FTIR (Pompei, 79), SIMS (Laacher See) and EPMA (Citlaltepetl). References: (1) Sharygin (1993); (2) Cioni (2000); (3) Chabiron et al. (2004).

nd, not determined.

Calibration routines have then been tested on glass inclusions of phonolite, trachyte and dacite compositions previously measured for water using other microanalytical techniques (Table 2). Phonolite calibrations were tested on glass inclusions in crystals of (1) the 79 AD Vesuvius eruption previously analysed by FTIR and EPMA (Cioni, 2000) and (2) the Upper Laacher See Tephra analysed by SIMS and EPMA (Sharygin, 1993; Table 2). Compositions of the Laacher See inclusions fall close to the lower limit of the phonolite field or in the trachyte field (Fig. 1A). Dacite calibration was tested on dacite glass inclusions from Citlaltepetl volcano (Mexico; Rossotti and Carrasco-Nunez, 2004) previously analysed by EPMA using a "by difference" approach calibrated on dacitic standards.
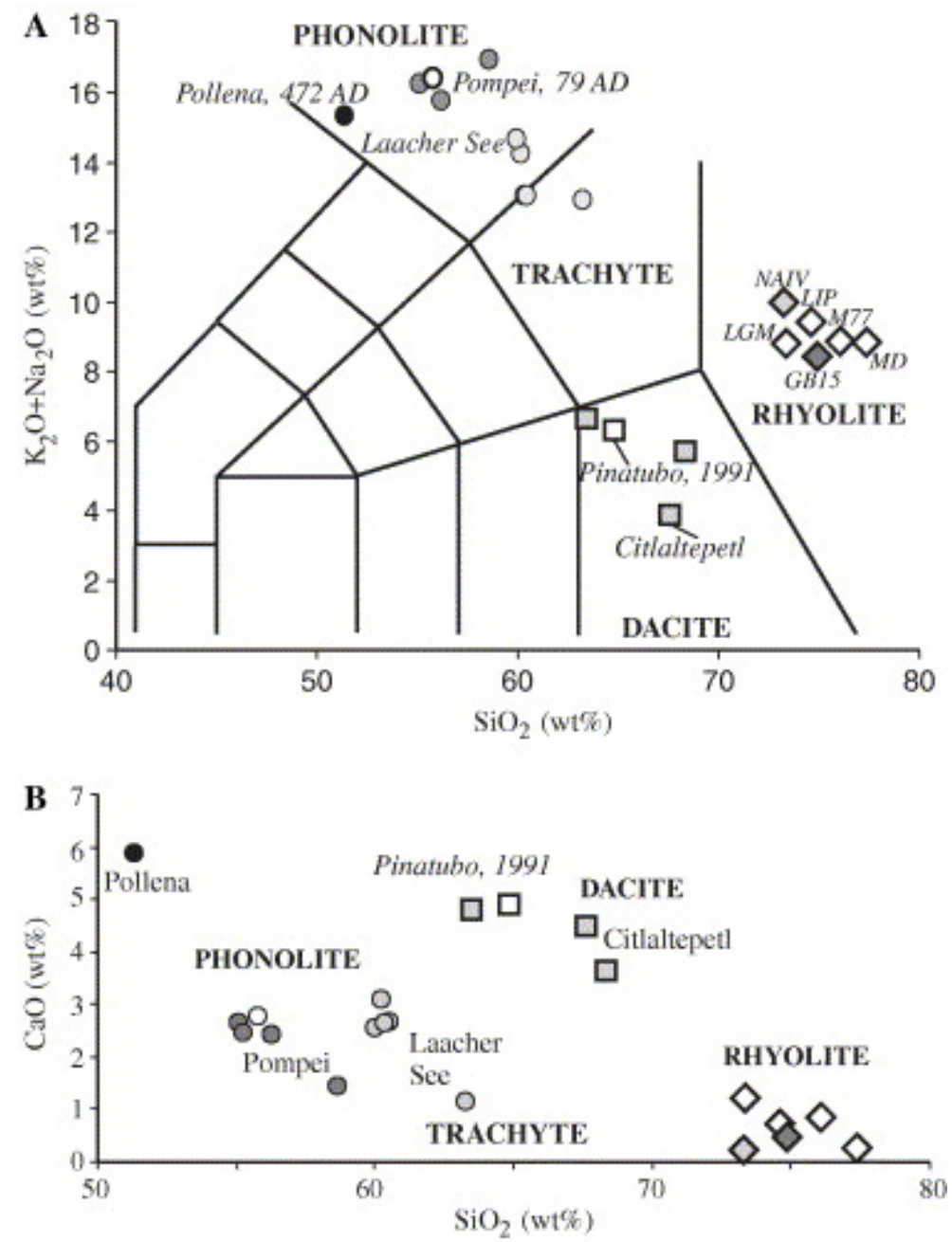

Fig. 1. Estimation of dry compositions of hydrous glass chips and glass inclusions analysed in this study. Black and white dots are hydrous phonolite glass chips from Pollena and Pompei eruptions of Mt. Vesuvius, respectively. Grey dots correspond to phonolite glass inclusions. White diamonds are metaluminous rhyolites. Dark grey diamonds are the peraluminous rhyolite series of glass chips and light-grey diamond is a peralkaline rhyolite glass chip used as external standard. Vesuvius Phonolites differ slightly in total alkali contents (A) but significantly for their alkali-earth (B) and iron contents (Table 1). 
Synthesis procedures of glasses and protocols for major and volatile element determination have been described in detail elsewhere and are summarized in Table 1. Fast drop-quench $\left(100-200{ }^{\circ} \mathrm{C} / \mathrm{s}\right)$ was used for synthesis of phonolite and peralkaline rhyolite glasses, while dacite and peraluminous rhyolite glasses experienced slow isobaric quench $\left(2-3^{\circ} \mathrm{C} / \mathrm{s}\right)$ (Table 1). The set of natural metaluminous rhyolite glasses corresponds to liquids cooled at the slowest quenchrate $\left(<0.01{ }^{\circ} \mathrm{C} / \mathrm{s}\right)$ and lowest isobaric pressure ( $<5$ bars) among our samples (Gottsmann and Dingwell, 2001). Phonolite and dacite standards were hydrated at higher temperatures $\left(1200-1400{ }^{\circ} \mathrm{C}\right)$ than peraluminous and peralkaline rhyolite glasses $\left(830-720^{\circ} \mathrm{C}\right)(\underline{\text { Table } 1})$.

The two selected sets of phonolite standards $\left(\mathrm{H}_{2} \mathrm{O}_{\mathrm{T}}\right.$ : $\left.<0.1-6.8 \mathrm{wt} \%\right)$ have dry compositions corresponding to those of the main explosive phases of the Pollena 472 AD and the Pompei 79 AD Vesuvius eruptions. These sets differ only slightly by their $\mathrm{Si}$ and alkali contents (Fig. $1 \mathrm{~A})$ and mainly by their $\mathrm{Ca}, \mathrm{Fe}$ and $\mathrm{MgO}$ contents, that are higher in the Pollena glasses (Fig. 1B; Table 1). Dacite standards $\left(\mathrm{H}_{2} \mathrm{O}_{\mathrm{T}}\right.$ : 0 $6.4 \mathrm{wt} \%$ ) have the lowest total alkali content in our series of glasses and their composition is that of the dacite erupted during the $1991 \mathrm{Mt}$. Pinatubo eruption (Table 1). In particular, Pinatubo dacite (adakite) has much less $\mathrm{K}_{2} \mathrm{O}(1.6 \mathrm{wt} \%)$ than phonolitic (9.4-10.2 wt\%) and rhyolitic glasses (4.1-5.8 wt\%), and it contains significant amounts of $\mathrm{MgO}$ and $\mathrm{CaO}$ (Fig. 1). The set of rhyolite standards was assembled in order to cover a large range of A/CNK (molar $\left.\mathrm{Al}_{2} \mathrm{O}_{3} / \mathrm{CaO}+\mathrm{Na}_{2} \mathrm{O}+\mathrm{K}_{2} \mathrm{O}\right)$ and water contents $\left(\mathrm{H}_{2} \mathrm{O}_{\mathrm{T}}: 0.2-9.5 \mathrm{wt} \%\right)$.

The adopted approach allowed exploring the influence of network-former vs. networkmodifier cation ratios and alkali metal/alkaline earth ratios on Raman analytical routines.

\section{Raman equipment and analytical routines}

\subsection{Analytical procedure}

Raman scattering was excited using $514.5 \mathrm{~nm}$ wavelength of an argon ion laser from Spectra Physics and measurements were performed with a LabRam HR800 (ENSLyon) spectrometer manufactured Jobin-Yvon equipped with a Peltier-cooled CCD detector. Glasses were analysed by focusing the laser beam on their surface in a $\sim$ $1 \mu \mathrm{m}$-wide spot under an Olympus microscope in confocal setting. The used pseudoconfocal system is characterized by low confocal performance but high system throughput. To reduce sampling depth we adopted a small confocal hole $(100 \mu \mathrm{m})$ and focused through the objective with the highest magnification (100x) (Table 3). The same microscope objective permits observation of the sample, focuses the laser beam onto the surface of the sample and collects the scattered radiation. Spectra were obtained in the $150-2000 \mathrm{~cm}^{-1}$ (Fig. 2; aluminosilicate framework vibration domain) and $3000-4000 \mathrm{~cm}^{-1}$ (Fig. 3; OH-stretching domain) ranges relative to the exciting laser light. A grating of 600 grooves $/ \mathrm{mm}$ was used to cover in one scan each domain. That clearly resulted in moderate resolution $\left( \pm 4 \mathrm{~cm}^{-1}\right)$, but high intensity of the collected signal. Average input laser power was about $20 \mathrm{~mW}$. Laser power at the sample was $7.4 \mathrm{~mW}$ and was periodically checked on a potentiometer placed on the 
sample holder before the sample analysis, with the same analytical conditions adopted for the glass analysis.

Table 3. : Comparison of settings adopted in this and previous researches for quantitative microRaman analyses of water in aluminosilicate glasses

\begin{tabular}{|c|c|c|c|c|c|c|c|c|c|c|}
\hline $\begin{array}{l}\text { Autho } \\
r\end{array}$ & $\begin{array}{l}\text { Spectrom } \\
\text { eter }\end{array}$ & $\begin{array}{l}\text { Grati } \\
\text { ng } \\
\left(\mathrm{mm}^{-}\right. \\
f^{-}\end{array}$ & $\begin{array}{l}\text { Magnificat } \\
\text { ion }\end{array}$ & $\begin{array}{l}\text { Las } \\
\text { er } \lambda \\
(\mathrm{nm} \\
)^{2}\end{array}$ & $\begin{array}{l}\text { Las } \\
\text { er } \\
\text { pow } \\
\text { er } \\
\text { (mW } \\
\text { ) }\end{array}$ & $\begin{array}{l}\text { Powe } \\
r \text { on } \\
\text { samp } \\
\text { le } \\
(\mathrm{mW})\end{array}$ & $\begin{array}{l}\text { Counti } \\
\text { ng } \\
\text { time } \\
\text { (s) }\end{array}$ & $\begin{array}{l}\text { Filt } \\
\text { er }\end{array}$ & $\begin{array}{l}\text { Baselin } \\
\text { e } \\
\text { correcti } \\
\text { on } \\
\text { (order) }\end{array}$ & $\begin{array}{l}\text { Detect } \\
\text { or }\end{array}$ \\
\hline \multirow[t]{2}{*}{$\begin{array}{l}\text { Thoma } \\
\text { s } \\
\underline{(2000)}\end{array}$} & $\begin{array}{l}\text { Triple } \quad X Y \\
\text { Dilor }\end{array}$ & 1800 & 80 & $\begin{array}{l}514 . \\
5\end{array}$ & 150 & 13 & $\begin{array}{l}3 \times 200 \\
(<1 \% \\
\left.\mathrm{H}_{2} \mathrm{O}\right)\end{array}$ & No & I & CCD \\
\hline & & 1800 & 80 & $\begin{array}{l}514 . \\
5\end{array}$ & 150 & 13 & $\begin{array}{l}3 \times 60 \\
(>1 \mathrm{wt} \\
\left.\% \mathrm{H}_{2} \mathrm{O}\right)\end{array}$ & No & I & CCD \\
\hline 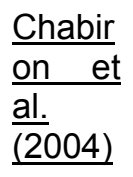 & $\begin{array}{l}\text { LabRam } \\
\text { Dilor }\end{array}$ & 600 & 80 & $\begin{array}{l}514 . \\
5\end{array}$ & 300 & $?$ & $1 \times 60$ & No & $?$ & CCD \\
\hline \multirow[t]{4}{*}{$\begin{array}{l}\text { This } \\
\text { paper }\end{array}$} & $\begin{array}{l}\text { LabRam } \\
\text { HR800 JY }\end{array}$ & 600 & 100 & $\begin{array}{l}514 . \\
5\end{array}$ & 20 & 7.4 & $\begin{array}{l}3 \times 30 \\
\left(\mathrm{H}_{2} \mathrm{O}\right) \\
(>1 \mathrm{wt} \\
\left.\% \mathrm{H}_{2} \mathrm{O}\right)\end{array}$ & 0.1 & II & CCD \\
\hline & & 600 & 100 & $\begin{array}{l}514 . \\
5\end{array}$ & 20 & 7.4 & $\begin{array}{l}1 \times 30 \\
(\mathrm{TOT}) \\
(>1 \mathrm{wt} \\
\left.\% \mathrm{H}_{2} \mathrm{O}\right)\end{array}$ & 0.1 & II & CCD \\
\hline & & 600 & 100 & $\begin{array}{l}514 . \\
5\end{array}$ & 20 & 7.4 & $\begin{array}{l}10 \times 30 \\
\left(\mathrm{H}_{2} \mathrm{O}\right) \\
(<1 \% \\
\left.\mathrm{H}_{2} \mathrm{O}\right)\end{array}$ & 0.1 & II & CCD \\
\hline & & 600 & 100 & $\begin{array}{l}514 . \\
5\end{array}$ & 20 & 7.4 & $\begin{array}{l}1 \times 30 \\
(\mathrm{TOT}) \\
(<1 \% \\
\left.\mathrm{H}_{2} \mathrm{O}\right)\end{array}$ & 0.1 & II & CCD \\
\hline
\end{tabular}

?, unknown. 


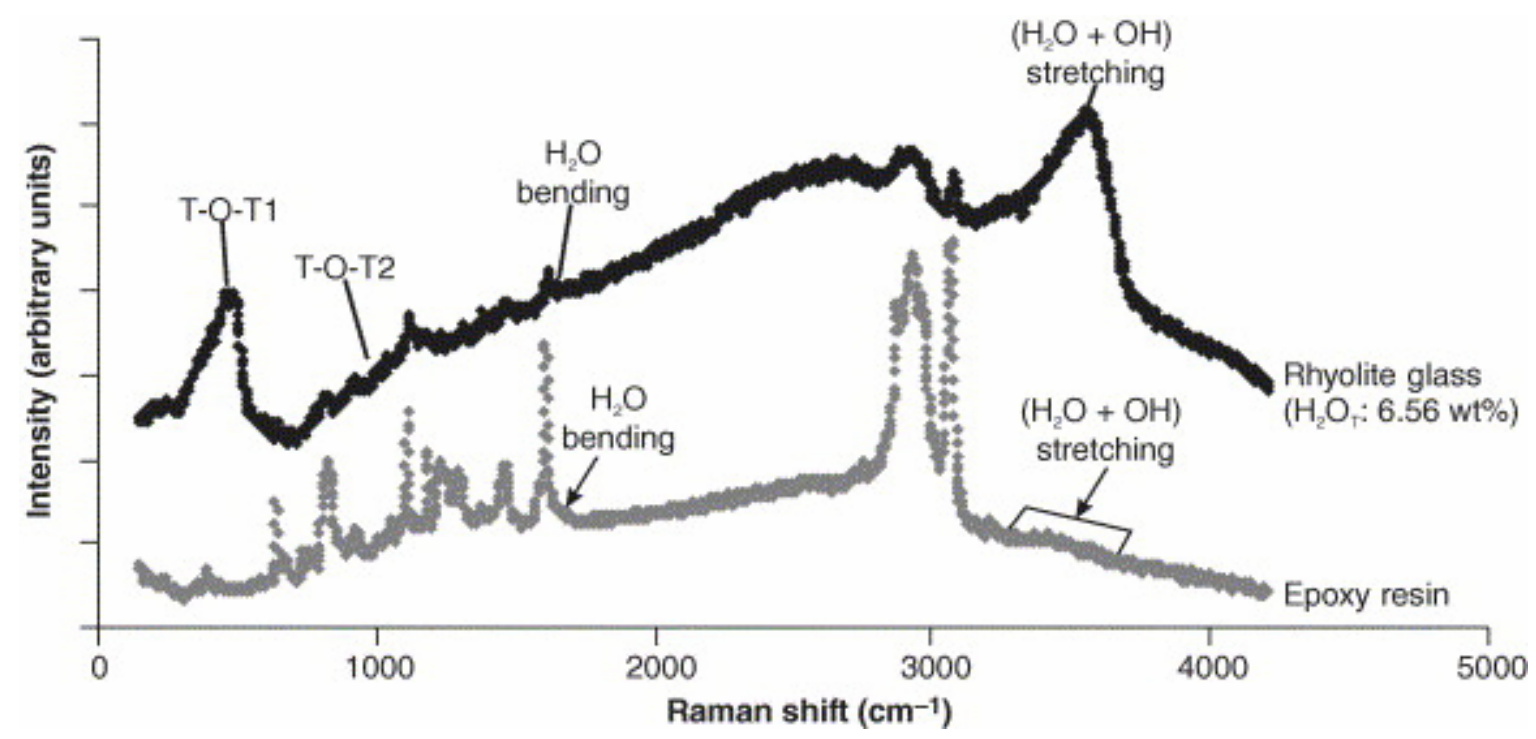

Fig. 2. Example of interference of embedding medium (polycarbonate epoxy resin) on Raman analysis of a glass sample. Raman spectra have been collected from the thin outer edge of a rhyolite glass chip and from embedding resin. In the spectrum of the glass, bands related to aluminosilicate framework (T-O-T), total water (molecular and hydroxyl) stretching and molecular water bending are associated with peaks related to underlying resin. Furthermore, resin interference results in a broad and steep fluorescent background, which significantly affects baseline treatment. In epoxy resin, low-intensity bands at ca. 3550 and $1630 \mathrm{~cm}^{-1}$ (arrows) reveal the presence of minor amounts of dissolved water. Further water can be absorbed during resin aging.

In glasses containing $>1 \mathrm{wt} \% \mathrm{H}_{2} \mathrm{O}_{\mathrm{T}}$, acquisition times were of $3 \times 30 \mathrm{~s}$ for the highfrequencies domain and of $1 \times 30 \mathrm{~s}$ for the low frequencies. Longer counting times were adopted for glasses with $<1 \mathrm{wt} \% \mathrm{H}_{2} \mathrm{O}_{\mathrm{T}}$ to increase the signal to noise ratio (Table 3). All spectra were obtained with the same optical configuration and at least three analyses were performed on each sample. 

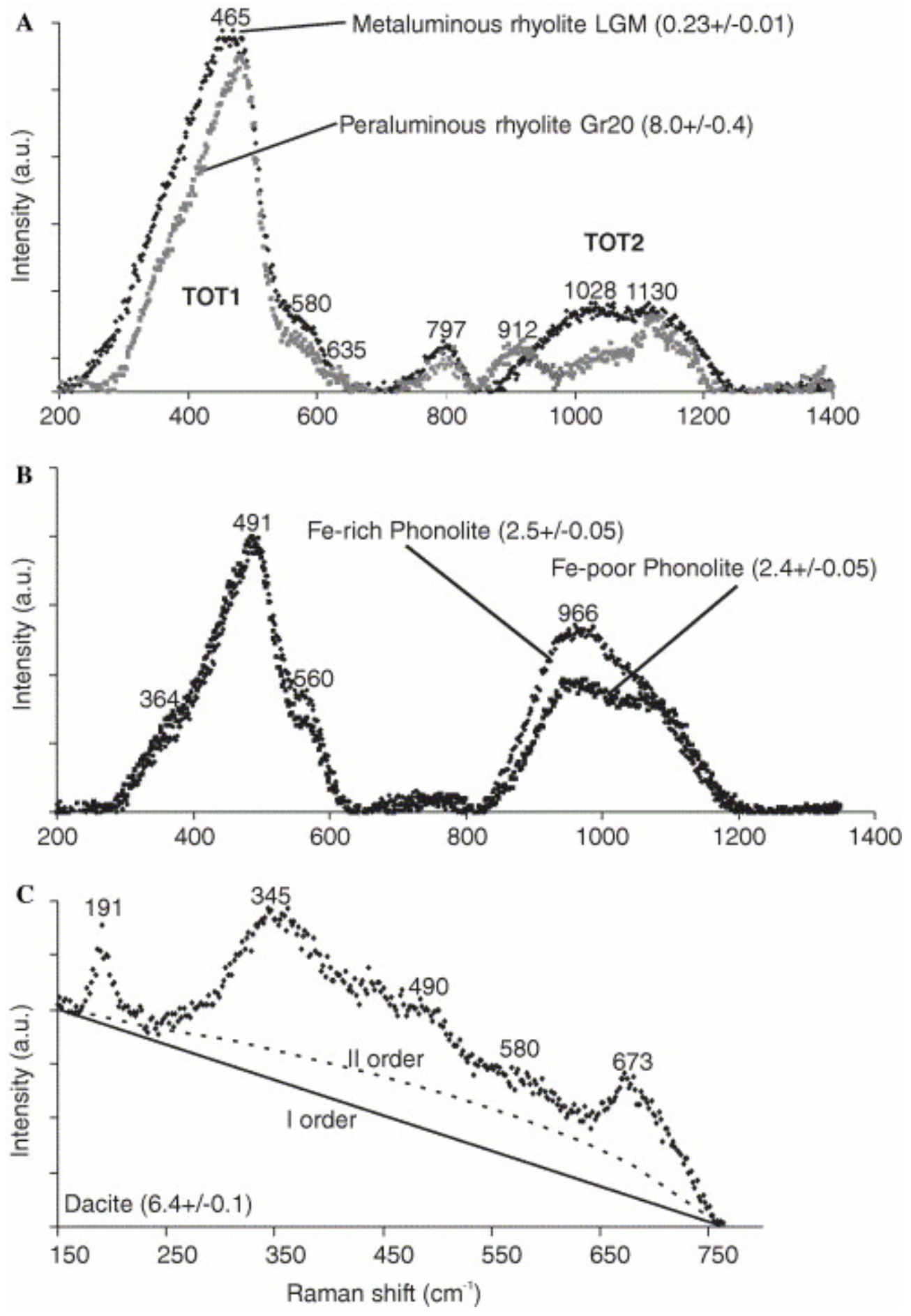

Fig. 3. Evolution of unpolarized TOT band shape as a function of glass composition. (A) Hydrous metaluminous and peraluminous rhyolites, (B) hydrous phonolites, (C) hydrous dacite. Spectra in (A and B) have been baseline-corrected. In hydrous dacite glasses, interfering peaks at 190, 345 and $670 \mathrm{~cm}^{-1}$ with intensity increasing with total water content are superimposed to the TOT1 feature and are attributed to increasing crystallization of nanolites (oxides) from the melt. Numbers in parentheses indicate the dissolved water contents. 


\subsection{Analysis optimization}

Several important concerns arise during Raman spectroscopic analysis of water in glass samples at room temperature: (1) fluorescence of the sample, (2) local glass heating by laser beam, (3) weak scattering of $\mathrm{O}-\mathrm{H}$ bonds, (4) background subtraction, and (5) band assignment. In the following paragraphs, we discuss the strategies we have adopted to reduce fluorescence and heating, to get an intense scattering signal and to treat and interpret the collected spectra.

In transparent or semi-transparent media and depending on confocal performance of the Raman equipment, the smallest signal sampling depth increases from $\sim 2 \mu \mathrm{m}$ to tens of microns, thus resulting in an approximately conical sampling volume. Consequently, Raman analysis of thin $(<100 \mu \mathrm{m}$; e.g. glasses prepared for FTIR analyses or standard thin sections) can result into high fluorescent backgrounds, or presence of peaks due to scattering from the underlying crystal or from the embedding polycarbonate epoxy resin (Fig. 2). In this way, scattering from $\mathrm{OH}$ groups in the epoxy resin (Fig. 2) or in the crystal (e.g., amphibole) can affect the determination of glass water content. Moreover, scattering from silicate or oxide phases dispersed in the glass under analysis can result in peaks interfering with the T-O-T vibration bands in the low-frequency side of the glass spectra (Di Muro et al., 2006). Therefore, one-side polished glass inclusions $>20 \mu \mathrm{m}$-thick and millimeterthick glass chips were selected to avoid collecting scattered signal from embedding medium.

A low hitting laser power and a short signal collection time (Table 3) were used to obtain intense and reproducible peaks and low local glass heating. In spite of the adopted cautions, heating and oxidation were detected in dacite glasses, which are possibly related to the presence of Fe-oxides nano-crystals crystallized during slow quench. Even with such a low laser power, oxidation of magnetite to maghemite can occur (de Faria et al., 1997). Maghemite scattering produces peaks in the 300$800 \mathrm{~cm}^{-1}$ region (Fig. $3 \mathrm{C}$ ) that overlap the bands related to the aluminosilicate glass framework (de Faria et al., 1997). This process results to have increasing importance from dry to water-rich glasses, in which element diffusion and microlite crystallization are faster (Di Muro et al., 2006).

\subsection{Spectra treatment}

Absolute intensity of Raman scattering $I(v)_{i}$ for a molecule $(i)$ is given by

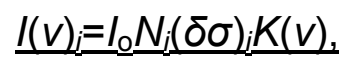

where $I_{\mathrm{o}}$ is the incident laser power, $N_{\mathrm{i}}$ the molar concentration of the scatterer in the excited volume and $(\delta \sigma)_{i}$ the differential scattering cross-section and $K(v)$ is the overall collection optics and spectrometer response.

$(\delta \sigma)_{i}$ expresses the dependence of molar scattering power of the species $(i)$ on (1) temperature $(T),(2)$ absorptivity of the material under analysis $\varepsilon(v),(3)$ vibrational frequency $v_{i}$ of scattered radiation and (4) path length $l$. Some of these parameters are frequency-dependent and usually they are not known. However, the frequency 
$\left(v_{i}\right)$ term has the main influence on scattering intensity, while $K(v)$ and $\varepsilon(v)$ terms have only a subordinate weight.

Relative band intensities are used for quantitative analyses instead of absolute ones as the intensity of collected Raman scattering is inherently weak and dependent on the stability of analytical conditions and the sampling depth. Relative intensities can be accurately determined and allow developing Raman spectroscopy in a quantitative way (Mysen and Virgo, 1986b, Thomas, 2000, Thomas, 2002, Chabiron et al., 2004, Arias et al., 2006 and Di Muro et al., 2006). In particular, assumption of equal scattering cross sections for two given species (es. hydroxyl $\mathrm{OH}$ and molecular $\mathrm{H}_{2} \mathrm{O}_{\mathrm{m}}$ ) allows direct derivation of their molar ratio in a sample by measuring the band height or area ratios of their Raman scattering $\left.\underline{(}_{(\mathrm{OH})} \underline{l}_{(\mathrm{H} 2 \mathrm{Om})}\right)$ (Chabiron et al., 2004).

\subsubsection{Baseline correction and detection limit}

The adopted analytical setting (Table 3) produces a signal/background ratio significantly decreasing from water-rich to water-poor glasses. Presence of significant background noise in water poor-glasses produces an unacceptably high error when characterizing the broad and low-intensity $\mathrm{OH}$-stretching band in samples with $<0.1 \mathrm{wt} \%$ total $\mathrm{H}_{2} \mathrm{O}$. Therefore, we estimate that $1000 \mathrm{ppm}$ is the detection limit for presently used Raman routines. Specific settings reducing background noise or enhancing Raman scattering are needed to reduce this detection limit. Therefore, we stress that, among the most widespread techniques, infrared spectroscopy (FTIR) remains the method of choice for accurate analysis of water-poor glasses (e.g., Pandya et al., 1992, lhinger et al., 1994 and Devine et al., 1995).

Raman spectra corrected for their baseline are then characterized in terms of band identification, band geometry (height, area, half-width) and band spectral composition. Variable baseline definitions in terms of wavenumber ranges (e.g., 150$800 \mathrm{~cm}^{-1}$ instead of $250-700 \mathrm{~cm}^{-1}$ ) or fit function (e.g., polynomial of second order) produce differences up to $25 \%$ (usually $<15 \%$ ) in band area measurement. A linear background in the range $3000-3800 \mathrm{~cm}^{-1}$ is observed for a rhyolite glass (M77, Table $1 ; 3.5 \mathrm{wt} \% \mathrm{H}_{2} \mathrm{O}$ ) dehydrated by heating during $3.5 \mathrm{~h}$ at $1500{ }^{\circ} \mathrm{C}$ and 1 bar. However, a second order polynomial represents a much better fit for steep fluorescent backgrounds, common in natural glasses (Fig. 2 and Fig. $3 \mathrm{C}$ ). In particular, the $\mathrm{OH}$-stretching band often sits on a background whose intensity significantly decreases with frequency. We subtracted to all our spectra a secondorder polynomial fitted to portion of the spectra where no Raman scattering was observed. The adoption of a baseline of constant type (second order polynomial) in a fixed wavenumber range $\left(150-800 \mathrm{~cm}^{-1}\right.$ and $\left.3000-3800 \mathrm{~cm}^{-1}\right)$ allows defining good calibration lines for determination of total dissolved water contents. However, this procedure can still produce some scattering when analyzing a glass series with variable water content and speciations because (1) the set of glasses may have variable fluorescence, which affects the importance of the baseline correction, (2) the deconvolution of the main bands in several contributions is strongly influenced by correct definition of the modes located near the tails of the total water band. In particular, the choice of a large wavenumber range for the definition of the background is crucial in getting an accurate characterization of the low and broad band related to water in water-poor samples $(<1 \mathrm{wt} \%)$ having a low signal/background ratio. 


\subsubsection{Band deconvolution and assignments}

Increasing amounts of dissolved water in aluminosilicate glasses result in increasing height and area of a broad band at $\sim 3550 \mathrm{~cm}^{-1}$ in the Raman spectra (Fig. 2). This band is present in both infrared (e.g., Stolper, 1982) and Raman spectra (e.g., Mysen et al., 1997) and results from the overlap of the $\mathrm{O}-\mathrm{H}$ stretching vibrations from hydroxyl groups $(\mathrm{OH})$ and water molecules $\left(\mathrm{H}_{2} \mathrm{O}_{\mathrm{m}}\right)$. Further low-intensity bands at $910 \mathrm{~cm}^{-1}$ (possibly due to stretching of $(\mathrm{Si}, \mathrm{Al})-\mathrm{OH}$ ) and $1620-1630 \mathrm{~cm}^{-1}$ (bending of molecular $\mathrm{H}_{2} \mathrm{O}_{\mathrm{m}}$ ) occur in the low-frequency region of spectra (Zotov and Keppler, 1998) (Fig. 2 and Fig. 3A).

For quantitative Raman analyses of water in rhyolitic samples, previous authors have normalized the high-frequency band $\left(\sim 3550 \mathrm{~cm}^{-1}\right)$ related to total water $\left(\mathrm{OH}+\mathrm{H}_{2} \mathrm{O}_{\mathrm{m}}\right)$ dissolved in the glass to a band produced by vibration of the T-O network ( $\mathrm{T}$ : tetrahedrally coordinated cations as $\mathrm{Si}, \mathrm{Al}$ ) in the low frequency region ( 470 $490 \mathrm{~cm}^{-1}$ ) (Thomas, 2000, Thomas, 2002 and Chabiron et al., 2004). This internal normalization procedure may result in high systematic errors because of (1) the presence of spurious scattering from the embedding medium or dispersed microlites (Fig. 3C) and (2) possible dependence of TOT band geometry on glass composition and structure (Fig. 3) (Di Muro et al., 2006). Chabiron et al. (2004) have already discussed the correction that must be introduced in internal calibrations in order to use them when scattering from other media occur. In the following, we show that normalization to an external standard glass of known water content (external normalization) allows overcoming these problems. In particular, an external normalization permits to eliminate the spectrometer-dependent $K(v)$ term, it does not require any correction for frequency- and temperature-dependence of the scattering intensity and it is potentially less composition-dependent than internal procedure.

For determination of water speciation $\left(\mathrm{OH} / \mathrm{H}_{2} \mathrm{O}_{m}\right)$, previous authors have deconvoluted the $3550 \mathrm{~cm}^{-1}$ band in four contributions (e.g., Mysen and Virgo, 1986b, Mysen et al., 1997 and Chabiron et al., 2004). They have assigned two bands ( 3300 and $\sim 3550 \mathrm{~cm}^{-1}$ ) to molecular water (Mysen and Virgo, 1986b and Mysen et al., 1997), and two other bands ( 3600 and mus6 $\mathrm{cm}^{-1}$ ) to hydroxyl groups $\mathrm{M}-\mathrm{OH}_{n}(\mathrm{M}$, metal), possibly with decreasing hydrogen bonding from low to high frequencies (McMillan and Remmele, 1986).

This deconvolution procedure implicitly assumes that no overlap exists between bands related to (symmetric and asymmetric) stretching of variably bonded $\mathrm{H}_{2} \mathrm{O}_{\mathrm{m}}$ and $\mathrm{OH}$. In order to test these assumptions, we initially deconvoluted the $\mathrm{H}_{2} \mathrm{O}_{\text {T }}$ band with a number of bands larger than four. The parameters of all bands were unconstrained for all samples and the iterative least-square fitting procedure was stopped when a low and almost constant residual $\left(\Delta x^{2}<10 \%\right)$ was obtained (Fig. 5 ).

Residual analysis indicate that four Gaussian-Lorentzian bands accurately describe the $\mathrm{H}_{2} \mathrm{O}_{\mathrm{T}}$ band in water-rich glasses, but a weak fifth band $\left(3710-3750 \mathrm{~cm}^{-1}\right)$ is required to fit spectra of glasses containing $<1 \mathrm{wt} \% \mathrm{H}_{2} \mathrm{O}_{\mathrm{T}}$ (Table 4; Fig. 5 ). In this research, we discuss whether the observed variation in relative height, area and position of the spectral components occur because of change of water speciation with total water content, glass dry composition, cooling rate and pressure (e.g., Silver et al., 1990 and Zhang et al., 1995) or if $\mathrm{H}$-bonding may play a major role. 
Table 4. : Results of deconvolution of total water band $\left(\sim 3.550 \mathrm{~cm}^{-1}\right)$ in five spectral components

\begin{tabular}{|c|c|c|c|c|c|c|c|c|c|c|}
\hline $\begin{array}{l}\text { Compositio } \\
\text { n }\end{array}$ & $\begin{array}{l}\mathrm{H}_{2} \mathrm{O}_{\text {tot }} \\
(\mathrm{wt} \%)\end{array}$ & $\begin{array}{l}\text { Ban } \\
\text { d } \quad \text { I } \\
\text { cm }^{-1}\end{array}$ & $\begin{array}{l}\text { Ban } \\
\text { d II } \\
\text { (cm } \\
-1 \text { ) }\end{array}$ & $\begin{array}{l}\text { Ban } \\
\text { d III } \\
\text { (cm } \\
-1 \text { ) }\end{array}$ & $\begin{array}{l}\text { Ban } \\
\text { d IV } \\
\text { (cm } \\
\left.{ }^{-1}\right)\end{array}$ & $\begin{array}{l}\text { Ban } \\
\text { d V } \\
\left(\mathrm{cm}^{-}\right. \\
)^{\prime}\end{array}$ & $\begin{array}{l}\mathrm{H}_{2} \mathrm{O}_{\mathrm{m}} \\
\text { Raman } \\
(\mathrm{wt} \%)\end{array}$ & $\begin{array}{l}\mathrm{H}_{2} \mathrm{O}_{\mathrm{m}} \\
\text { FTIR } \\
\text { (wt\%) }\end{array}$ & $\begin{array}{l}\mathrm{OH} \\
\text { Raman } \\
\text { (wt\%) }\end{array}$ & $\begin{array}{l}\text { OH } \\
\text { FTIR } \\
\text { (wt\%) }\end{array}$ \\
\hline Dacite (PIN) & $\begin{array}{l}2.12- \\
6.36\end{array}$ & $\begin{array}{l}3254 \\
- \\
3379\end{array}$ & $\begin{array}{l}345 \\
0- \\
348 \\
3\end{array}$ & $\begin{array}{l}355 \\
6- \\
357 \\
1\end{array}$ & $\begin{array}{l}362 \\
0- \\
365 \\
8\end{array}$ & $\begin{array}{l}\text { Abs } \\
\text { ent }\end{array}$ & & & & \\
\hline Rhyolites & $\begin{array}{l}3.5- \\
9.46\end{array}$ & $\begin{array}{l}3253 \\
- \\
3371\end{array}$ & $\begin{array}{l}345 \\
6- \\
348 \\
9\end{array}$ & $\begin{array}{l}356 \\
6- \\
357 \\
8\end{array}$ & $\begin{array}{l}363 \\
3- \\
364 \\
6\end{array}$ & $\begin{array}{l}\text { Abs } \\
\text { ent }\end{array}$ & & & & \\
\hline $\begin{array}{l}\text { Rhyolite(LG } \\
\text { M151) }\end{array}$ & $\begin{array}{l}0.24 \pm 0 \\
.01\end{array}$ & $\begin{array}{l}\text { Abs } \\
\text { ent }\end{array}$ & $\begin{array}{l}343 \\
4\end{array}$ & $\begin{array}{l}355 \\
2\end{array}$ & $\begin{array}{l}363 \\
5\end{array}$ & 3742 & 0.10 & nd & 0.15 & nd \\
\hline $\begin{array}{l}\text { Rhyolite(LIP } \\
\text { 151) }\end{array}$ & $\begin{array}{l}0.6 \pm 0 . \\
03\end{array}$ & $\begin{array}{l}\text { Abs } \\
\text { ent }\end{array}$ & $\begin{array}{l}342 \\
6\end{array}$ & $\begin{array}{l}353 \\
4\end{array}$ & $\begin{array}{l}362 \\
9\end{array}$ & 3752 & 0.18 & nd & 0.41 & nd \\
\hline $\begin{array}{l}\text { Phonolite } \\
\text { (472 AD) }\end{array}$ & $\begin{array}{l}2.52- \\
6.70\end{array}$ & $\begin{array}{l}3265 \\
- \\
3327\end{array}$ & $\begin{array}{l}342 \\
1- \\
346 \\
6\end{array}$ & $\begin{array}{l}353 \\
3- \\
355 \\
7\end{array}$ & $\begin{array}{l}360 \\
7- \\
361 \\
9\end{array}$ & $\begin{array}{l}\text { Abs } \\
\text { ent }\end{array}$ & & & & \\
\hline $\begin{array}{l}\text { Phonolite } \\
\text { (79AD) }\end{array}$ & $\begin{array}{l}2.38- \\
6.80\end{array}$ & $\begin{array}{l}3237 \\
- \\
3336\end{array}$ & $\begin{array}{l}343 \\
7- \\
345 \\
8\end{array}$ & $\begin{array}{l}353 \\
8- \\
355 \\
5\end{array}$ & $\begin{array}{l}361 \\
2- \\
361 \\
8\end{array}$ & $\begin{array}{l}\text { Abs } \\
\text { ent }\end{array}$ & & & & \\
\hline P5A $(79 A D)^{a}$ & $\begin{array}{l}0.69 \pm 0 \\
.10\end{array}$ & 3357 & $\begin{array}{l}342 \\
1\end{array}$ & $\begin{array}{l}349 \\
1\end{array}$ & $\begin{array}{l}359 \\
8^{\underline{\underline{b}}}\end{array}$ & 3709 & $\begin{array}{l}0.29 \pm 0 \\
.01\end{array}$ & $\begin{array}{l}0.22 \pm 0 \\
.12\end{array}$ & $\begin{array}{l}0.39 \pm 0 \\
.01\end{array}$ & $\begin{array}{l}0.47 \pm 0 \\
.02\end{array}$ \\
\hline $\begin{array}{l}\text { P2C1 } \\
\left(^{79 A D)^{a}}\right.\end{array}$ & $\begin{array}{l}0.89 \pm 0 \\
.04\end{array}$ & $\begin{array}{l}\text { Abs } \\
\text { ent }\end{array}$ & $\begin{array}{l}342 \\
7\end{array}$ & $\begin{array}{l}351 \\
9\end{array}$ & $\begin{array}{l}362 \\
9\end{array}$ & 3754 & $\begin{array}{l}0.36 \pm 0 \\
.01\end{array}$ & $\begin{array}{l}0.36 \pm 0 \\
.06\end{array}$ & $\begin{array}{l}0.52 \pm 0 \\
.02\end{array}$ & $\begin{array}{l}0.54 \pm 0 \\
.01\end{array}$ \\
\hline $\begin{array}{l}\text { P2C2 } \\
(79 A D)^{a}\end{array}$ & $\begin{array}{l}1.04 \pm 0 \\
.12\end{array}$ & 3395 & $\begin{array}{l}346 \\
7\end{array}$ & $\begin{array}{l}353 \\
7\end{array}$ & $\begin{array}{l}360 \\
7\end{array}$ & 3732 & $\begin{array}{l}0.51 \pm 0 \\
.03\end{array}$ & $\begin{array}{l}0.40 \pm 0 \\
.03\end{array}$ & $\begin{array}{l}0.54 \pm 0 \\
.03\end{array}$ & $\begin{array}{l}0.64 \pm 0 \\
.10\end{array}$ \\
\hline T2D $(79 A D)^{a}$ & $\begin{array}{l}3.62 \pm 0 \\
.03\end{array}$ & 3364 & $\begin{array}{l}344 \\
9\end{array}$ & $\begin{array}{l}354 \\
2\end{array}$ & $\begin{array}{l}361 \\
8\end{array}$ & $\begin{array}{l}3737 \\
\underline{b}\end{array}$ & $\begin{array}{l}1.91 \pm 0 \\
.06\end{array}$ & $\begin{array}{l}2.35 \pm 0 \\
.07\end{array}$ & $\begin{array}{l}1.64 \pm 0 \\
.05\end{array}$ & $\begin{array}{l}1.48 \pm 0 \\
.01\end{array}$ \\
\hline
\end{tabular}

Water speciation $\left(\mathrm{OH} / \mathrm{H}_{2} \mathrm{O}_{m}\right)$ is determined as the area ratio of $(\mathrm{V}+\mathrm{IV}+\mathrm{III}) /(\mathrm{I}+\mathrm{II})$ and compared with FTIR data on the same glass inclusions (data from Cioni, 2000). The phonolite glass inclusion T2D has experienced limited water-loss consequent to glass heating during EPMA analysis and contains lower $\mathrm{H}_{2} \mathrm{O}_{\mathrm{m}}$ than measured by FTIR. Note the presence of band $\mathrm{V}$ in water-poor glasses that we attribute to weakly $\mathrm{H}$-bonded hydroxyl species.

nd, not determined.

${ }^{a}$ Melt inclusions from Cioni (2000).

${ }^{\mathrm{b}}$ Very weak. 


\section{Results}

\subsection{Influence of glass composition and structure on water band normalization procedures}

The adoption of normalization procedures using $\mathrm{H}_{2} \mathrm{O}_{\mathrm{T}} / \mathrm{TOT}$ ratio for water analysis in glasses (Thomas, 2000 and Chabiron et al., 2004) may depend on sample preparation or texture, and introduce a potentially large compositional-dependent term (TOT) into the analytical procedure. Raman spectra of our volcanic glasses exhibit two main broad and asymmetric bands in the low frequency region, the first between 250 and $650 \mathrm{~cm}^{-1}$ (TOT1) and the second between 850 and $1250 \mathrm{~cm}^{-1}$ (TOT2) (Fig. 3). A third low-intensity band is evident in rhyolites at $\sim 800 \mathrm{~cm}^{-1}$.

TOT1 is the most intense band in all glasses we analysed and it has been chosen for internal normalization for water analysis in rhyolite glasses (Thomas, 2000 and Chabiron et al., 2004). The TOT1 feature envelops the vibrations of structural units formed by variable tetrahedra numbers building the aluminosilicate framework of the glass (Sharma et al., 1981 and McMillan, 1984) and possibly of metal-oxygen polyhedra (Brawer and White, 1977). Therefore, band position and shape are expected to evolve as a result of the modification in glass composition and structure. TOT1 position shifts to higher frequencies from rhyolites to dacites and phonolites (Fig. 3). A further positive shift is also observed as a function of $\mathrm{H}_{2} \mathrm{O}$ content (Fig. 4A). These observations agree with previous data on simple aluminosilicate glasses (Mysen and Virgo, 1986a). TOT1 aspect ratio (height/half width ratio) increases with dissolved water content in all sets except Pompei phonolite (Fig. 4A) and, mostly, with $\mathrm{Al}_{2} \mathrm{O}_{3}$ /alkali ratio (Fig. 4B). In anhydrous glasses, moderate broadening of the TOT1 feature is observed from metaluminous rhyolites to dacites to phonolites and it is largely due to increasing intensity of a mode at $560-580 \mathrm{~cm}^{-1}$. In our glass sets, this band accounts for $<5 \%$ of the TOT1 band in rhyolites and increases to $14 \%$ in anhydrous dacite glass and $8-19 \%$ in phonolites (Pollena: 14-19\%; Pompei: 8$13 \%)$. Its area or height are not correlated with total dissolved water. Irrespective of the detailed interpretation of all spectral component of the TOT1 band, a general agreement exists on the correlation of the intensity of TOT1 high-frequency side with the degree of depolymerization of the glass network (see Mysen, 1988 and Zotov and Keppler, 1998 for detailed discussion). More specifically, the $580 \mathrm{~cm}^{-1}$ band can be attributed to a mixed stretch-bend vibration in $\mathrm{Si}_{2} \mathrm{O}_{5}{ }^{2-}$ structural units (Furukawa et al., 1981). Therefore, it is not surprising that the most significant TOT1 band broadening is observed in the Si-poor, alkali-and alkali-earth rich phonolite glasses from Pollena. 

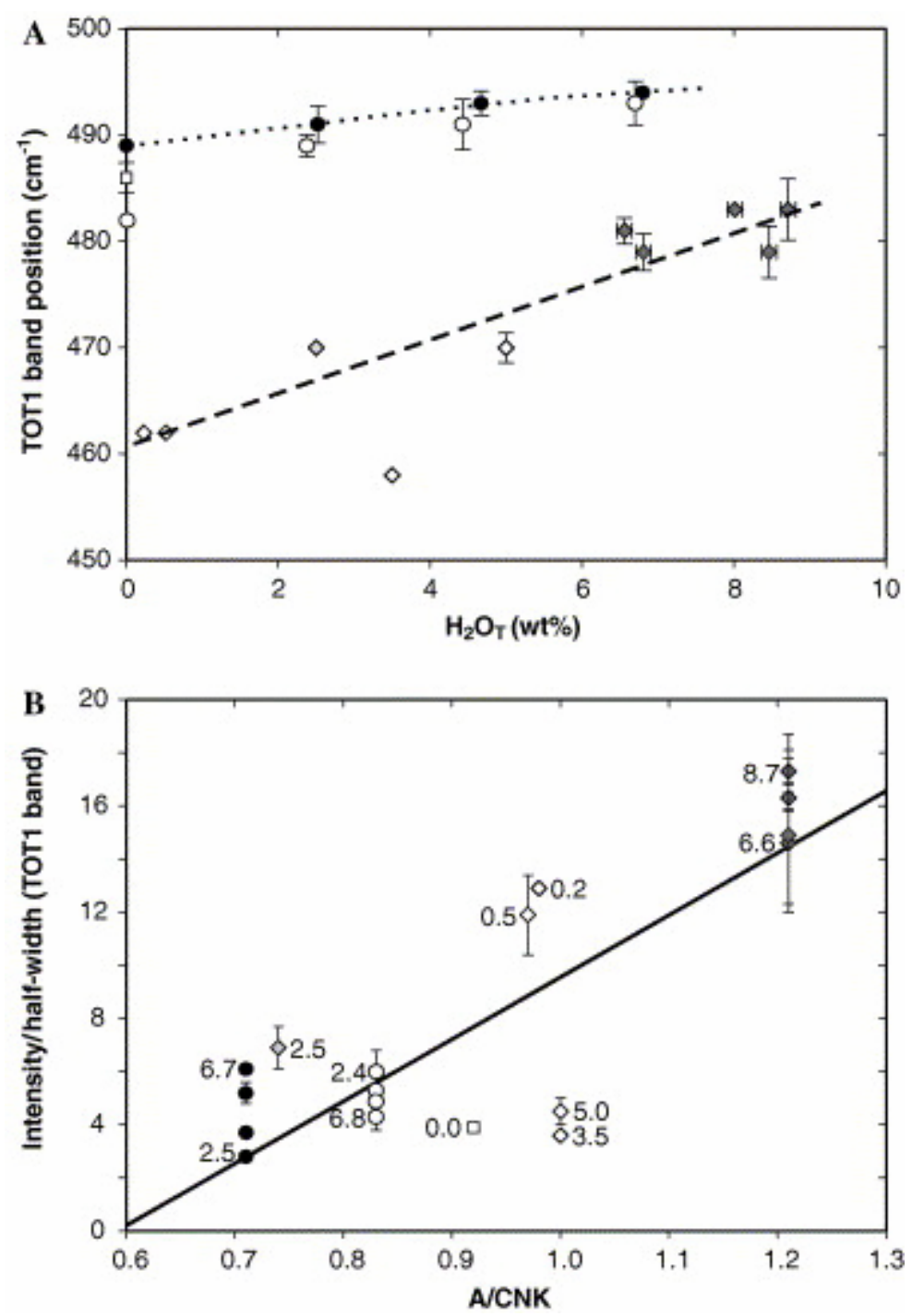

Fig. 4. Variation of TOT1 band position (A) and aspect ratio (B) as a function of dissolved water content and alumina vs. alkali ratio ( $/$ /CNK: molar $\mathrm{Al}_{2} \mathrm{O}_{3} / \mathrm{CaO}+\mathrm{NaO}+\mathrm{K}_{2} \mathrm{O}$ ). Numbers indicate dissolved water contents. The data of microlite-bearing hydrous dacite glasses are not reported because microlite scattering hinders correct determination of TOT1 parameters. Large scattering of values for some water-rich peraluminous glasses may reflect some sample heterogeneity. These glasses are the only samples containing a significant volume fraction of gas bubbles. Symbols as in Fig. 1. Lines are only "guides for the eyes" even if obtained by data fitting.

TOT2 is classically assigned to the T-O stretching of $Q^{n}$ species $\left(Q, \mathrm{TO}_{4}\right.$ units; $\mathrm{n}$, number of bridging oxygens) and its spectral composition is strongly influenced by substitution of $\mathrm{Al}^{3+}$ and $\mathrm{Fe}^{3+}$ for $\mathrm{Si}^{4+}$ as network-forming cation (Mysen, 1988, Neuville and Mysen, 1996 and Sharma et al., 1997). In natural volcanic glasses, relative intensity of TOT1/TOT2 decreases with glass depolymerization (Di Muro et al., 2006). In particular, the height of the mode at $\sim 1030 \mathrm{~cm}^{-1}$ strongly decreases and the height of a band at $910 \mathrm{~cm}^{-1}$ increases from metaluminous to peraluminous rhyolites. Finally, entry of increasing percentages of $\mathrm{Fe}^{3+}$ in the tetrahedral network results in increasing height of a mode at $.966 \mathrm{~cm}^{-1}$ (Di Muro et al., 2006). This mode is absent in peraluminous rhyolites, may have a very low height in metaluminous rhyolites (Fig. $\underline{3}$ ) but it is intense in phonolites, especially in the iron-rich Pollena glass (Fig. 3B). 


\subsection{Determination of water speciation}

\subsubsection{Comparison between Raman and FTIR speciation data}

The shape and the spectral distribution of the broad $\mathrm{OH}$-stretching band at $\sim$ $3550 \mathrm{~cm}^{-1}$ vary significantly with $\mathrm{H}_{2} \mathrm{O}_{\mathrm{T}}$ content (Fig. 5 and Fig. 6), glass composition (Fig. 7) and glass structure (Fig. 8). In glasses with $\mathrm{H}_{2} \mathrm{O}_{\mathrm{T}}>0.7 \mathrm{wt} \%$, an asymmetric band is observed in the domain $3000-3800 \mathrm{~cm}^{-1}$ (Fig. 5 and Fig. 6). In water-rich glasses $\left(\mathrm{H}_{2} \mathrm{O}_{T}>4.6 \mathrm{wt} \%\right)$, this band shifts to higher frequency with increasing glass Si-content, from $3500-3520 \mathrm{~cm}^{-1}$ in phonolites to $3550-3570 \mathrm{~cm}^{-1}$ in dacite and rhyolite (Fig. 6). Among the analysed glass series, hydrous rhyolite glasses display the narrowest $\mathrm{OH}$-stretghing bands (e.g., Fig. 6A). Full width at half height (FWHH) of total water band is very similar in rhyolites and dacite (Fig. 6B) and increases of ca. $20 \%$ in phonolites, which show an evident shoulder near $3300 \mathrm{~cm}^{-1}$ (Figs. $6 \mathrm{C}$ and D). In water-poor glasses $\left(\mathrm{H}_{2} \mathrm{O}_{\mathrm{T}}<0.9 \mathrm{wt} \%\right)$, the $\mathrm{OH}$-stretching band is more symmetric than in water-rich samples (Fig. 5B), it is often polymodal and shows a tail at frequencies $>3700 \mathrm{~cm}^{-1}$ that is not observed in water-rich glasses (Fig. 5A).

In order to compare Raman and FTIR water speciation data, we deconvoluted the total water band in five components (I, 3240-3395 cm $3520-3580 \mathrm{~cm}^{-1}$; IV, 3610-3660 cm $\mathrm{cm}^{-1}$, V, 3710-3750 cm $\mathrm{cm}^{-1}$ ) (Fig. 6; Table 4). The average positions of bands I-IV closely match those determined for rhyolite glasses by Chabiron et al. (2004). We calculated the ratio between the sums of the areas of $\mathrm{I}+\mathrm{II}$ (attributed to $\mathrm{H}_{2} \mathrm{O}_{\mathrm{m}}$ ) and III $+\mathrm{IV}+\mathrm{V}$ (attributed to $\mathrm{OH}$ ) bands. For phonolite compositions, results are compared with speciation data determined by FTIR on the same glass inclusions from Pompei eruption (Table 4) and, for the other compositions, with FTIR trends from the literature (Fig. 7). These comparisons reveal that Raman data only rawly reproduce the typical evolution of water speciation, with a general increase of molecular water $\left(\mathrm{H}_{2} \mathrm{O}_{\mathrm{m}}\right)$ with total dissolved water and $\mathrm{OH}$ species dominating on molecular water at $\mathrm{H}_{2} \mathrm{O}_{\mathrm{T}}<2.5 \mathrm{wt} \%$. 

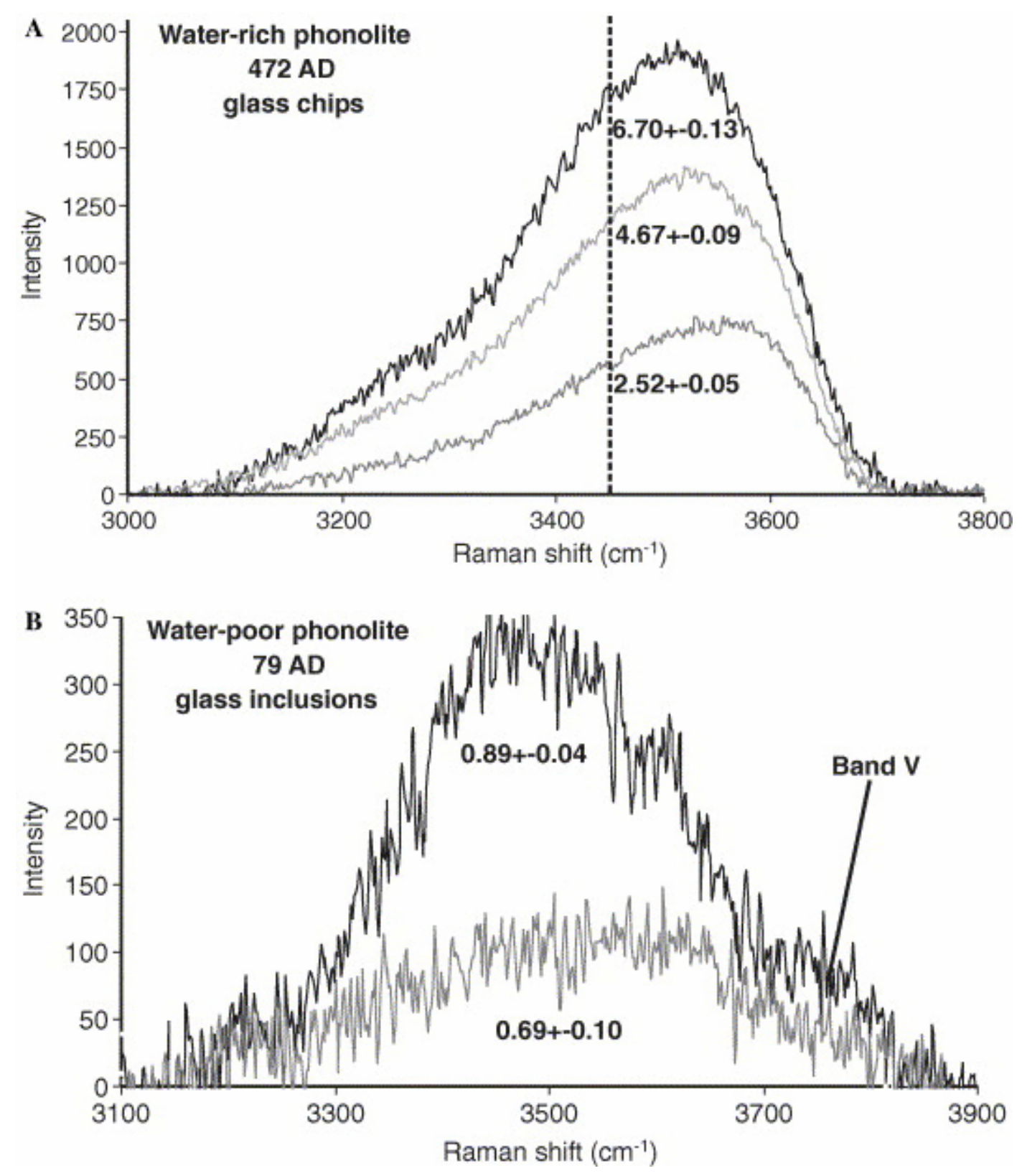

Fig. 5. Shape evolution of unpolarized $\mathrm{OH}$-stretching band in phonolite glasses after II order baseline subtraction. Band topology evolves from symmetric and polymodal in glasses with $\mathrm{H}_{2} \mathrm{O}_{\mathrm{T}}<1.0 \mathrm{wt} \%$ to asymmetric and unimodal in water-rich glasses. (A) Increase of molecular water content with total dissolved water content results in increasing intensity of the low frequency band side $\left(<3500 \mathrm{~cm}^{-1}\right)$. (B) Decreasing $\mathrm{OH}$ hydrogen bonding in water-poor glasses results in the appearance of a component that we interpret as related to weakly $\mathrm{H}$-bonded $\mathrm{OH}$ groups in the high-frequency band side $\left(>3700 \mathrm{~cm}^{-1}\right)$. 

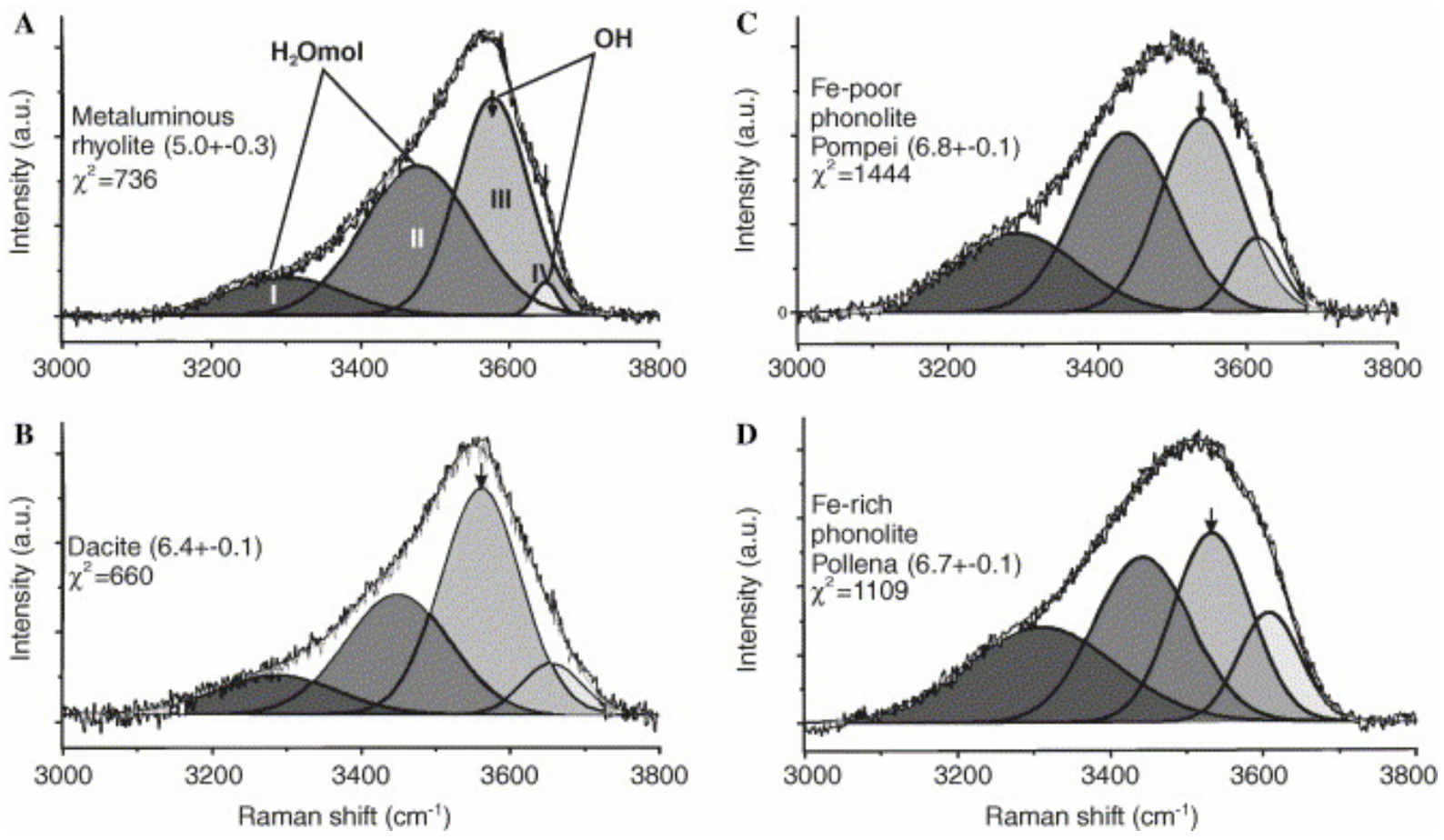

Fig. 6. Deconvolution of unpolarized OH-stretching band in water-rich glasses (after II order baseline subtraction) in four contributions related to molecular water (bands I + II) and hydroxyl groups (bands III + IV) in water-rich metaluminous rhyolite (A), dacite (B) and phonolite (C and D) glasses. Overlap between contributions related to tightly $\mathrm{H}$-bonded $\mathrm{OH}$ and loosely $\mathrm{H}$-bonded $\mathrm{H}_{2} \mathrm{O}_{m}$ can occur at the level of band II. Note the progressive increase of intensity of band IV (moderately $\mathrm{H}$-bonded $\mathrm{OH}$ ) relative to band III (arrow, strongly $\mathrm{H}$-bonded $\mathrm{OH}$ ) from Ca-poor rhyolite $(\mathrm{A})$ and Pompei phonolite $(\mathrm{C})$ to Ca-rich Pollena phonolite (D). Numbers in brackets indicate total dissolved water content as determined by Karl-Fischer titration (KFT). 

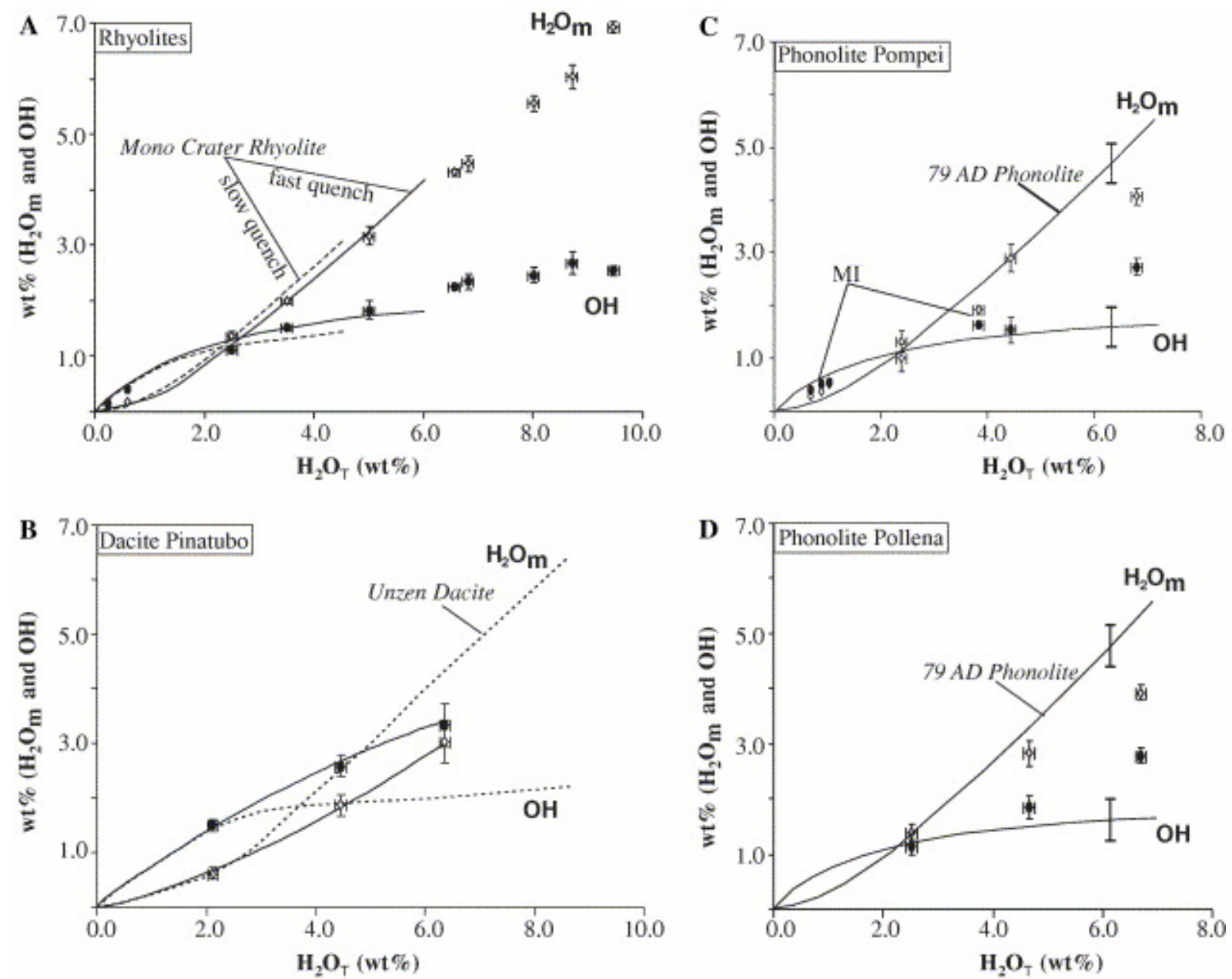

Fig. 7. Raman water speciation in the four series of analysed hydrous glasses calculated on the basis of (bands I + II)/(bands III + IV + V) area ratios. Speciation curves are from Silver et al. (1990) for metaluminous rhyolite, Cioni (2000) for phonolites and Ohlhorst et al. (2001) for dacite. Water speciation trends are shown for rhyolites synthesized using both rapid quench $\left(\sim 400^{\circ} \mathrm{C} / \mathrm{s}\right.$ ) and slow quench $\left(3^{\circ} \mathrm{C} / \mathrm{s}\right)$ apparatus (Silver et al., 1990). Filled symbols: hydroxyl (bands III + IV); open symbols: molecular water (bands I+II). In (C) Ml are melt inclusions in phenocrysts from $79 \mathrm{AD}$ Pompei eruption (able 2). 

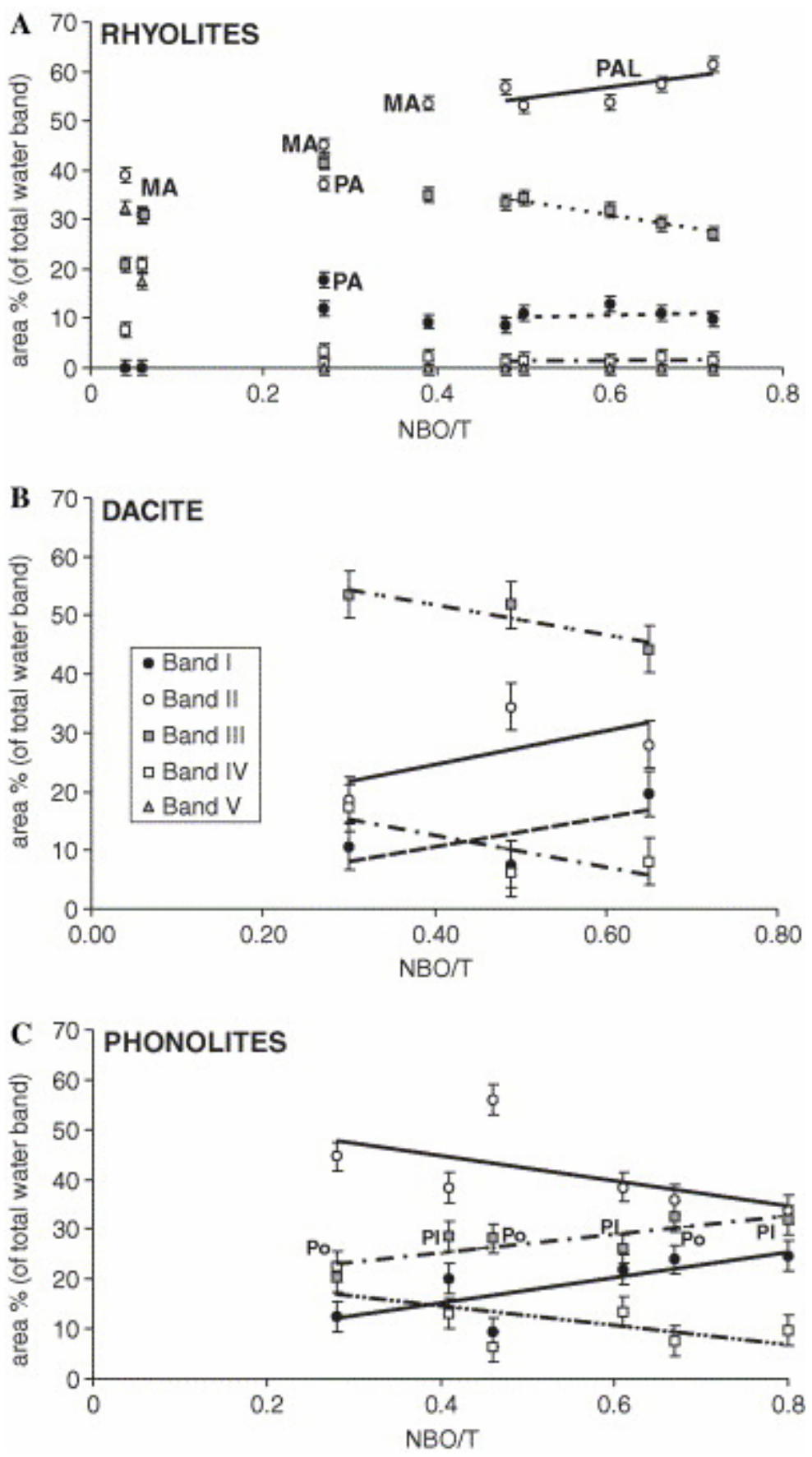

Fig. 8. Evolution of the integrated area ratios of the five bands identified in the deconvolution of the total water band in Raman spectra. MA: metaluminous; PA: peralkaline; PAL: peraluminous. Increasing amounts of NBOs are expected to stabilize tightly $\mathrm{H}$-bonded $\mathrm{OH}$ and $\mathrm{H}_{2} \mathrm{O}_{m}$ species (bands III and I, respectively). The decrease of band III and the concomitant increase of band II in dacite and rhyolite glasses with $\mathrm{NBO}>0.3$ suggest that band II actually may represent the overlap of the contributions of both weakly $\mathrm{H}$-bonded $\mathrm{H}_{2} \mathrm{O}_{\mathrm{m}}$ and very strongly $\mathrm{H}$-bonded $\mathrm{OH}$. 
In the case of rhyolite glasses, Raman data satisfactorily compare with FTIR trends for metaluminous rhyolites (Fig. 7A). Peraluminos rhyolites deviate from this trend and apparently contain a higher proportion of water as hydroxyls. Among Si-rich glasses, the main discrepancy between our Raman data and FTIR trends is found for the dacite glass series (Fig. 7B). This series, produced with slow isobaric quenching rate (Table 1), maintains a high hydroxyl content even at water contents $>3 \mathrm{wt} \%$ (Fig. 7B). Slow cooling rates are expected to favour $\mathrm{H}_{2} \mathrm{O}_{\mathrm{m}}$ over $\mathrm{OH}$ (Stolper, 1982; Fig. 7A) and therefore cannot be at the origin of the observed trend in the dacite series. We stress the mafic character of our dacite (adakite) and its low total alkali $\left(\mathrm{Na}_{2} \mathrm{O}+\mathrm{K}_{2} \mathrm{O}\right)$ content and very low $\mathrm{K}_{2} \mathrm{O} / \mathrm{Na}_{2} \mathrm{O}$ ratio. (Table 1 ). Alkalis (especially $\mathrm{K}_{2} \mathrm{O}$ ) may bond water molecules (see e.g., Pichavant et al., 1992). Moreover, Ohlhorst et al. (2001) have obtained similar water speciation data for andesite glasses having $\mathrm{K}_{2} \mathrm{O} / \mathrm{Na}_{2} \mathrm{O}$ ratio comparable to those of our dacite series (0.3).

Systematic discrepancies appear in water-rich (>4.6 wt\%) alkaline glasses. The adopted deconvolution procedure results in apparent high hydroxyl contents with respect to the FTIR trend determined by Cioni (2000) on phonolite inclusions from the 79 AD Vesuvius eruption. (Figs. 7C and D). Fast cooling-rate of our drop-quenched glass chips could, at least in part, explain the apparent high hydroxyl content respect to melt inclusions slowly cooled in the eruptive column. Appreciable differences in composition between our glass sets and natural glasses (Table 1 and Table 2) could also be at the origin of the observed differences. Some compositional heterogeneity in the natural samples results in significant data scattering reported as error bars on the phonolite speciation trend in Fig. 7. Our comparison with FTIR analyses performed on the same glass inclusions (79 AD phonolite) suggests that Raman deconvolution procedure may discriminate between hydroxyl and molecular species in water-poor glasses (Table 4). A more extended comparison between high-quality FTIR and Raman data on alkaline glasses is in progress with the aim of better discriminating between compositional and cooling effects and precision of the deconvolution procedure on Raman speciation data.

\subsubsection{Water speciation vs. $\mathrm{O}-\mathrm{H}$ hydrogen bonding strength}

In alkali-bearing aluminosilicate glasses both hydroxyl and molecular water experience a broad range of hydrogen bonding strength between them and with the glass network (Wu, 1980, Uchino et al., 1991 and Xue and Kanzaki, 2004). The ratio between weakly and strongly $\mathrm{H}$-bonded $\mathrm{O}-\mathrm{H}$ increases with the field strength (or electronegativity) of the network modifiers in the order $\mathrm{K}-\mathrm{Na}-\mathrm{Ca}-\mathrm{Mg}-\mathrm{Al}(\underline{\mathrm{Wu}, 1980})$ and it decreases with increasing amounts of NBOs in the glass structure. "Free" $\mathrm{M}$ $\mathrm{OH}$ groups (i.e., without any bonding to the network) are expected to become important in mafic melts (Xue and Kanzaki, 2004). Increasing $\mathrm{H}$-bonding weakens the $\mathrm{O}-\mathrm{H}$ bond and in that way decreases the frequency of the $\mathrm{O}-\mathrm{H}$ stretching vibration.

The change of relative areas or intensities of the five identified spectral components as a function of total water content, glass composition and glass structure must, therefore, be interpreted in terms of both coexistence of two different hydrous species $\left(\mathrm{H}_{2} \mathrm{O}_{\mathrm{m}}\right.$ vs. $\left.\mathrm{OH}\right)$ with variable relative ratios and evolution of their bonding environment. The discrepancies we observe bewteen Raman and FTIR data raise 
the question of whether the procedure adopted to deconvolute the total water band in Raman spectra allows discrimination between water species (i.e., $\mathrm{OH}$ vs. $\mathrm{H}_{2} \mathrm{O}_{m}$ ) or whether it fails because this band envelops a continuous spreading of $\mathrm{H}$-bonding strength and distance.

Mysen and Virgo, 1986b and Mysen et al., 1997 suggest a correlation between the intensity of the two contributions in the low frequency side (components I and II; Fig. 6) and both the (alkali + alkali-earth)/silica ratio and the molecular water content of the glass. Specifically, Mysen and Virgo (1986b) report that components I and II are positively correlated with $\mathrm{Ca} / \mathrm{Si}$ and $\mathrm{Na} / \mathrm{Si}$ ratios, respectively. Our sets of natural glasses have a much more complex bulk composition than simple $\mathrm{CaO}-\mathrm{Na}_{2} \mathrm{O}-\mathrm{SiO}_{2}$ glasses studied by Mysen and Virgo (1986b). Therefore, it is not straightforward to relate variations of band heights or areas to a specific chemical or structural parameter. As a first order approach, we compare the evolution of band area ratios with the calculated NBO contents of glasses (Fig. 8).

If the deconvolution procedure discriminates between $\mathrm{H}_{2} \mathrm{O}_{\mathrm{m}}$ and $\mathrm{OH}$ species, bands $\mathrm{V}$, IV and III should result from stretching of $\mathrm{OH}$ groups with increasing $\mathrm{H}$-bonding. Bands I and II should instead arise from stretching (symmetric and asymmetric) of two groups of molecular water with different strength of $\mathrm{H}$-bonding (Whittington et al., 2001 and Xue and Kanzaki, 2004). In this hypothesis, the ratios between bands $\mathrm{V} /(\mathrm{IV}+\mathrm{III})$ and II/I should decrease with the increase of strong hydrogen-bond acceptors such as NBOs.

Some observations are compatible with this interpretation. Band $\mathrm{V}$ (weakly bond $\mathrm{OH}$ ) is found only in glasses with very low NBOs (Fig. 8A). In our glass sets, band $V$ is present only in water-poor rhyolite glasses and band IV (moderately bonded $\mathrm{OH}$ ) progressively decreases with NBOs in all glass sets. Band IV is significantly more important in phonolites and dacites than in rhyolites (alkali-poor glasses). It is worth noting that band IV is more important in $\mathrm{Ca}$, Mg-rich phonolite from Pollena (band IV: $11-14 \%$ ) than in the alkali-earth poorer phonolite from Pompei (band IV: 6-9\%). That is what is expected if high-field strength cations favour the formation of weakly to moderately bonded $\mathrm{O}-\mathrm{H}(\underline{\mathrm{Wu}, 1980})$. The area fraction of band III (strongly $\mathrm{H}$-bonded $\mathrm{OH}$, in our hypothesis) increases in rhyolites with $\mathrm{NBO}<0.3$ and in phonolites, but decreases in rhyolites with NBO $>0.3$ and dacite. It is worth noting that all rhyolites (metaluminous, peraluminous and peralkaline) plot on a same trend. The decrease of band III with NBOs and a parallel increase of band II observed in rhyolites and dacite is what one could expect if overlap between bands produced by $\mathrm{H}_{2} \mathrm{O}_{m}$ and $\mathrm{OH}$ oscillators occurs. This trend is not correlated with ion field strength as dacite have constant alkali content and peralkaline rhyolites contain more $\mathrm{Na}_{2} \mathrm{O}$ than metaluminous glasses.

If Bands I and II represent stretching of only tightly and loosely bond $\mathrm{H}_{2} \mathrm{O}_{\mathrm{m}}$, respectively, one should expect that band I (strongly $\mathrm{H}$-bonded $\mathrm{H}_{2} \mathrm{O}_{\mathrm{m}}$ ) increases with NBOs. That actually occurs in rhyolites in the NBO range $<0.3$ and in the dacite and phonolite sets. Conversely, band II increases in rhyolites and decreases in phonolites in the explored NBO ranges. That may suggest that overlap between strongly $\mathrm{H}-$ bonded $\mathrm{OH}$ and weakly bonded $\mathrm{H}_{2} \mathrm{O}_{\mathrm{m}}$ occurs in the wavenumber range attributed to band II. However, this overlap should result in an underestimation of the hydroxyl content by Raman spectroscopy, and not an overestimation as found in rhyolite and 
phonolite glasses (Figs. 7A, C and D). We stress that the procedure of relating the area ratios instead of the intensity ratios to water speciation better accounts for this possible overlap. In conclusion, we infer that our water-rich glass sets actually contain higher $\mathrm{OH}$ contents than natural glasses, possibly because of their faster cooling.

\subsection{Quantification of total dissolved water content}

In Si-rich glasses, the ratios between height (Thomas, 2000) or area (Chabiron et al., 2004) of the $\sim 3550 \mathrm{~cm}^{-1}$ (total $\mathrm{H}_{2} \mathrm{O}_{\mathrm{T}}$ ) and $\sim 490 \mathrm{~cm}^{-1}$ (aluminosilicate network-TOT1) bands have been reported to linearly correlate with total water content dissolved in the glasses (internal calibration procedure). We individuate at least two different linear trends, one for peraluminous rhyolites and the second for phonolites, and metaluminous and peralkaline rhyolites (Figs. 9A and B). As expected, the best fits are found for series of hydrous glasses having the same major element compositions (i.e., phonolites). Significantly larger scattering is observed in the composite rhyolite glass series. It is worth noting that on height ratios- $\mathrm{H}_{2} \mathrm{O}_{\mathrm{T}}$ diagrams both phonolite glass series define the same calibration (Figs. $9 \mathrm{~A}$ and $\mathrm{B}$ ). Peraluminous rhyolites, that have the highest aspect ratio (Fig. $4 \mathrm{~B}$ ) have also very high height ratios (Figs. 9A and $B$ ). Their normalized intensities fall on a calibration line similar to that defined by Thomas (2000) for albite, pegmatite and leucogranite samples (Fig. 9A). In area ratios- $\mathrm{H}_{2} \mathrm{O}_{T}$ diagrams, only water-poor metaluminous glasses fits on the calibration curve defined by Chabiron et al. (2004). Our results clearly show that the differences in analytical setting and spectrometer performances (Table 3) have a considerable influence on Raman calibrations.

Calibrations based on area ratios are more composition dependent than those using height ratios (Fig. 9B). This is likely due to (1) influence of glass composition of water speciation and $\mathrm{H}$-bonding strength and therefore band area and (2) larger errors in the determination of band areas relative to determination of band intensities. Moreover, calibrations using area ratios cannot be used for glasses in which the TOT1 band area is not accurately measurable because of the existence of interfering peaks from the embedding medium, as it is the case for the dacite series (Fig. 3C). 

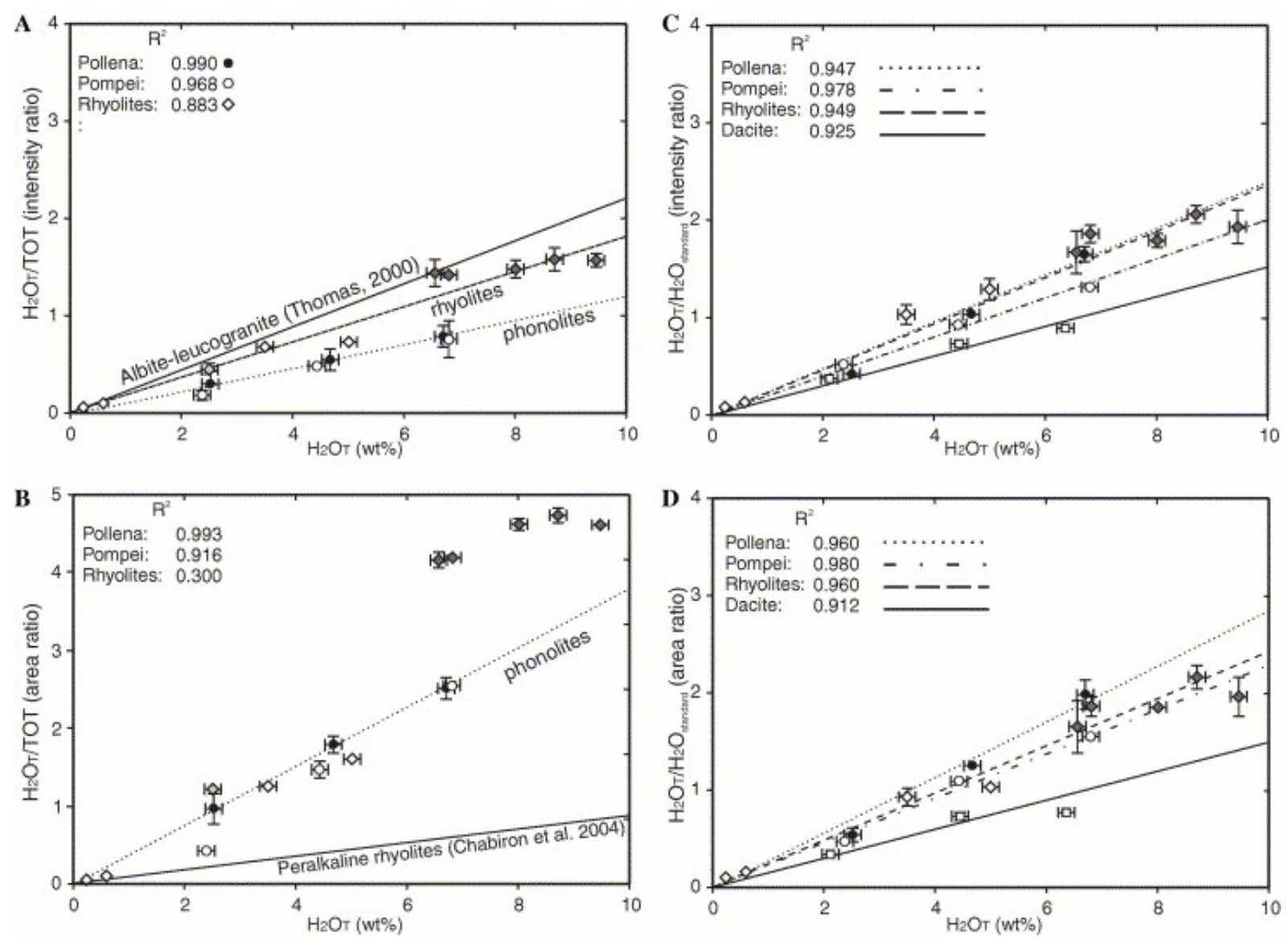

Fig. 9. Calibration lines for total water content in hydrous rhyolites, dacites and phonolites glasses. Internal calibration is based on ratios of height (A) or area (B) of the total $\mathrm{H}_{2} \mathrm{O}_{\mathrm{T}}\left(\sim 3550 \mathrm{~cm}^{-1}\right)$ and TOT1 bands $\left(\sim 490 \mathrm{~cm}^{-1}\right)$. TOT1 band area of hydrous dacites cannot be accurately determined due to interference with other bands due to presence of microlites. External normalization of total $\mathrm{H}_{2} \mathrm{O}$ band $\left(\sim 3550 \mathrm{~cm}^{-1}\right)$ height (C) or area (D) to total $\mathrm{H}_{2} \mathrm{O}$ band of a glass standard can be preferred when TOT1 band cannot accurately be measured or for the analysis of chemically heterogeneous samples. This procedure significantly reduces the composition-dependence of calibration lines.

In cases where the TOT1 band cannot be accurately characterized, normalization to the water band of an external standard can be adopted (external calibration procedure; Figs. $9 \mathrm{C}$ and $\mathrm{D}$ ). We choose the peralkaline rhyolite glass SMN 49 $\left(2.5 \mathrm{wt} \% \mathrm{H}_{2} \mathrm{O}_{\mathrm{T}}\right)$ as external standard. This approach results in much lower composition-dependence of the calibrations (Fig. 10A). In fact, the normalization to a single composition-independent band of an external standard allows defining a reasonable linear correlation even in a highly heterogeneous series such as that of the rhyolites $\left(r^{2}=0.96\right)$ (Figs. 9C and D). Slight increase in data scattering likely depends on error associated to $\mathrm{OH}$-stretching band measurements and analysis repeatability in several analytical sessions. In fact, it is important to stress that the external procedure is more sensitive to small errors in focusing on the glass surface than the internal one. In this last procedure both TOT1 and $\mathrm{H}_{2} \mathrm{O}_{\mathrm{T}}$ bands are affected in a similar way by intensity variations due to variable sampling depth. 


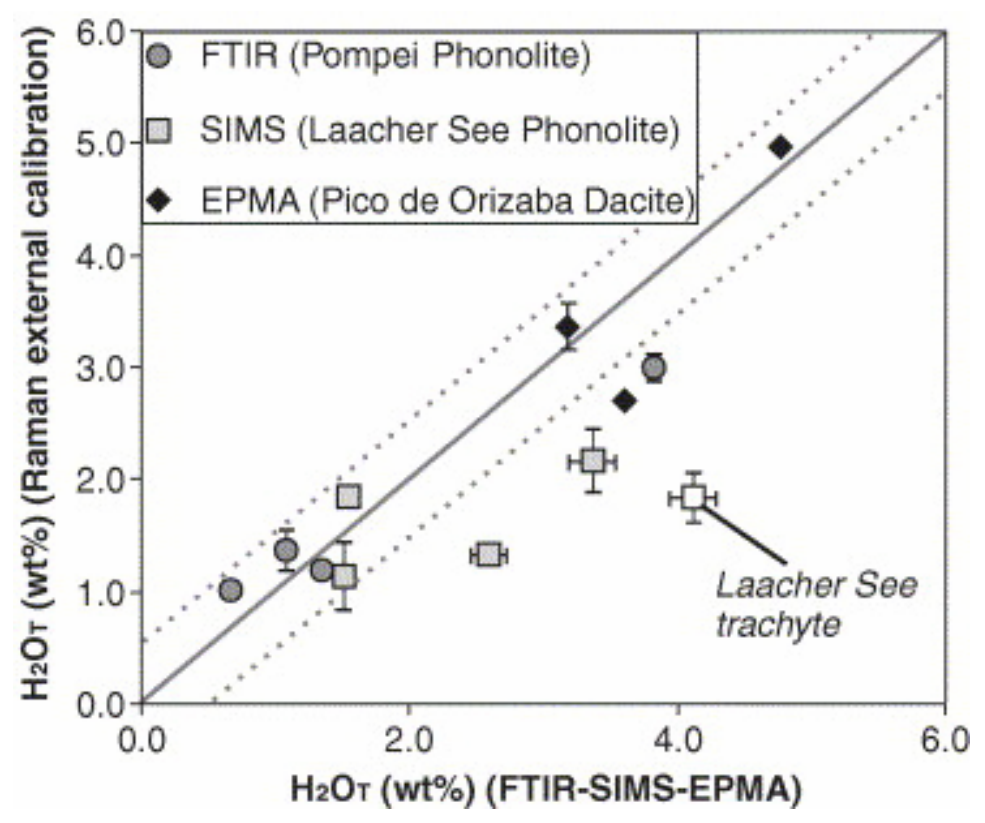

Fig. 10. Comparison between Raman and FTIR, SIMS and EMPA analyses of phonolite-trachyte and dacite glass inclusions from Mt. Vesuvius (Pompei 79 AD), Laacher See and Pico de Orizaba volcanoes. Dotted lines define a deviation of $\pm 0.5 \mathrm{wt} \%$ from the $1: 1$ line. Systematically lower Raman water contents in some glass inclusions are attributed to water-loss subsequent to glass heating and damage during previous microanalysis (SIMS, EMPA) performed before Raman analysis.

We tested the external calibration method on a series of phonolitic-trachytic glass inclusions from Vesuvius (Italy) and Laacher See volcanoes (Germany) and dacite glass inclusions from Pico de Orizaba volcano (Mexico) (Fig. 1; Table 2). All glass inclusions were exposed and polished for Raman analysis. The deviation among Raman data and those collected using other techniques increases as a function total dissolved water content (Fig. 10) and is largest in glasses previously analysed by SIMS. These differences are possibly due to (1) water-loss from glass inclusions during SIMS or EMPA analyses before Raman analyses and (2) scattering from the embedding dry crystal that reduces the intensity of the water band. This last effect cannot be accounted for when using external calibrations. Moreover, large error bars in some inclusions are attributed to heterogeneities at the micrometer scale that the small laser beam can reveal when moving from the core to the rim of the glass inclusion. The large difference observed with the trachytic inclusion cannot be attributed to compositional dependence of the calibrations because trachyte and phonolites fall on a very similar calibration line (Di Muro et al., 2006).

\section{Conclusion}

Numerous microanalytical techniques have been recently developed for the quantification of water content (SIMS, FTIR, Raman and EMPA) and speciation (FTIR, Raman) in natural glasses. However, due to their high composition dependence, all these techniques must be calibrated. These calibrations critically hinge on standardization procedures which are established using series of glasses of which compositions are as close as possible to the glasses under study. Our data on 
natural phonolite, dacite and rhyolite glasses together with data on albite, leucogranite and pegmatite glasses of Thomas (2000), rhyolite glasses of Chabiron et al. (2004), obsidians (Arias et al., 2006) and basaltic melt inclusions (Thomas, 2002) strongly support the reliability of the Raman technique for the quantification of $\mathrm{H}_{2} \mathrm{O}$ content in synthetic and natural glasses. $\mathrm{H}_{2} \mathrm{O}$ contents in glass chips or in glass inclusions in crystals are linearly correlated with the height or the area of the $\mathrm{OH}$ stretching band at $\approx 3550 \mathrm{~cm}^{-1}$. Normalization of glass water band intensities to that of an external standard still allows the analysis microcrystalline samples and permit to define calibrations that are faintly composition-dependent. Confocal Raman spectrometry has a very good accuracy (in the best conditions up to $0.1 \%$ Thomas, 2000 ), a good repeatability ( $<6.5 \%$ over periods of months on a broad water range), a moderate sensitivity ( $\sim 1000 \mathrm{ppm})$ and an excellent spatial resolution (1-2 $\mu \mathrm{m})$ compared to other methods (Devine et al., 1995). Improvement of the analytical procedure to increase the signal/background ratio (background reduction and/or Raman scattering enhancement) should lead to significant improvements of the determination of the $3550 \mathrm{~cm}^{-1}$ band area and thus of $\mathrm{H}_{2} \mathrm{O}_{\mathrm{T}}$ determination.

Comparison of heterogeneous (rhyolites) to homogeneous (phonolites, dacites) silicic glass series clearly evidences the dependence of internal Raman calibration methods on glass peraluminosity. Composition-dependence arises from the control exerted by glass composition and structure on spectral distribution of TOT normalizing bands and total water band. Changes of bulk composition modify the glass structure and are detected by evolution of the low frequency side of the spectrum (Di Muro et al., 2006). Our research shows that, in a given glass group (e.g., phonolites), internal Raman calibrations that uses the TOT1 band are quite insensitive to moderate differences in $\mathrm{Ca}, \mathrm{Mg}$ or $\mathrm{Fe}$ contents. These cations, instead, seem to play a major role in (1) affecting hydroxyl bonding in water-rich samples and (2) modify TOT2 band spectral composition by entry of $\mathrm{Fe}^{3+}$ in the glass network.

Glass composition and structure influence water speciation and bonding environment and therefore the spectral composition of the total water band. In fact, this band is the convolution of distinct scattering contributions from both hydroxyl and molecular water with highly variable hydrogen bonding. Therefore, physical (cooling rate, temperature, pressure) or chemical factors able to modify water speciation and glass structure potentially affect Raman calibrations. The occurrence in glasses of both molecular and hydroxyls with variable $\mathrm{H}$-bond strength must be taken into account to interpret the spectral distribution of total water band in terms of water speciation. Our preliminary results suggest that the adopted deconvoluted procedure might be successful in glasses with low NBOs contents whose amount influences the ratio between weakly and strongly $\mathrm{H}$-bonded water species. In glasses with high NBOs, contributions related to stretching of weakly bond $\mathrm{H}_{2} \mathrm{O}_{\mathrm{m}}$ and strongly $\mathrm{H}$-bond $\mathrm{OH}$ may overlap in the frequency range of band II $\left(\sim 3450 \mathrm{~cm}^{-1}\right)$.

Application of Raman analytical procedures to natural samples indicates that the main concerns for application of microRaman spectrometry to the study of small glass volumes (glass inclusions, glass filaments) are the confocal performance of the available equipment, and the possible heating and oxidation of the sample. Further studies are needed to assess the applicability of confocal microRaman spectroscopy to iron rich, Si-poor (e.g., basalts, tephrites). 


\section{Acknowledgments}

A.D.M. has been supported by a Research Training Network fellowship funded by the European Union (Research Training Network on Volcano Dynamics). We are indebted with $\mathrm{C}$. Romano, R. Thomas, $\mathrm{H}$. Behrens and a third anonymous reviewer for their insightful comments that stimulated a critical review of a first version of this paper. R. Cioni and G. Carrasco are acknowledged for providing glass inclusions of the $79 \mathrm{AD}$. Vesuvius and Citlaltepetl fall eruptions respectively. Special acknowledgments for V. Sharygin and S. Kovyazin (Institute of Mineralogy and Petrography, Novosibirsk, Russia) S. Simakin and E. Potapov (Institute of Microelectronics, Yaroslavl', Russia) for the EMPA and SIMS analyses of Laacher See melt inclusions. Thanks to A. Michel for performing the hydrogen manometry and halogen analyses of rhyolite glasses.

\section{References}

Arias et al., 2006 A. Arias, M. Oddone, G. Bigazzi, A. Di Muro, C. Principe and P. Norelli, New data for the characterisation of Milos obsidians, J. Radioanal. Nuclear Chem. 268 (2006) (2), pp. 371-386.

Brawer and White, 1977 S.A. Brawer and W.B. White, Raman spectroscopic investigation of the structure of silicate glasses, II. Soda-alkaline earth-alumina ternary and quaternary glasses, J. Non-Cryst. Solids 23 (1977), pp. 261-278.

Carroll and Blank, 1997 M.R. Carroll and J.G. Blank, The solubility of $\mathrm{H}_{2} \mathrm{O}$ in phonolitic melts, Am. Mineral 82 (1997), pp. 549-556.

Chabiron et al., 2004 A. Chabiron, J. Pironon and D. Massare, Characterization of water in synthetic rhyolitic glasses and natural melt inclusions by Raman spectroscopy, Contrib. Miner. Petrol. 146 (2004), pp. 485-492.

Chen et al., 2004 J. Chen, H. Zheng, W. Xiao, Y. Zg and K. Weng, Raman spectroscopic study of $\mathrm{CO}_{2}-\mathrm{NaCl}-\mathrm{H}_{2} \mathrm{O}$ mixtures in synthetic fluid inclusions at thigh temperatures, Geochim. Cosmochim. Acta 68 (2004), pp. 1335-1360.

Chou et al., 1990 I.M. Chou, J.D. Pasteris and J.C. Seitz, High-density volatiles in the system C-O-H-N for the calibration of a laser Raman microprobe, Geochim. Cosmochim. Acta 54 (1990), pp. 535-543.

Cioni, 2000 R. Cioni, Volatile content and degassing processes in the AD 79 magma chamber at Vesuvius, Contrib. Miner. Petrol. 140 (2000), pp. 40-54.

de Faria et al., 1997 D.L.A. de Faria, S. Venâncio Silva and M.T. de Oliveira, Raman microspectroscopy of some iron oxides and oxyhydroxides, J. Raman Spectrosc. 28 (1997), pp. 873-878.

Devine et al., 1995 J.D. Devine, J.E. Gardner, H.P. Brack, G.D. Layne and M.J. Rutherford, Comparison of microanalytical methods for estimating $\mathrm{H}_{2} \mathrm{O}$ contents of silicic volcanic glasses, Am. Miner. 80 (1995), pp. 319-328. 
Di Muro et al., 2004 A. Di Muro, A. Neri and M. Rosi, Contemporaneous convective and collapsing eruptive dynamics: The transitional regime of explosive eruptions, Geophys. Res. Lett. 31 (2004), p. L10607

Di Muro et al., 2006 Di Muro, A., Giordano, D., Villemant, B., Montagnac, G., Romano, C., 2006. Influence of composition and thermal history of volcanic glasses on water content determination by microRaman spectrometry. Appl. Geochem. in press.

Dubessy et al., 1989 J. Dubessy, B. Poty and C. Ramboz, Advances in C-O-H-N-S fluid geochemistry based on micro-Raman spectrometric analysis of fluid inclusions, Eur. J. Miner. 1 (1989), pp. 517-534.

Furukawa et al., 1981 T. Furukawa, K.E. Fox and W.B. White, Raman spectroscopic investigation of the structure of silicate glasses, III. Raman intensities and structural units in sodium silicate glasses, J. Chem. Phys. 75 (1981), pp. 3226-3237.

Gottsmann and Dingwell, 2001 J. Gottsmann and D.B. Dingwell, The cooling of frontal flow ramps: a calorimetric study on the Rocche Rosse rhyolite flow, Lipari, Aeolian Islands, Italy, Terra Nova 13 (2001), pp. 157-164.

lhinger et al., 1994 Ihinger, P.D., Hervig, R.L., McMillan, P.F., 1994. Analytical methods for volatiles in glasses. In: Carrol, M., Holloway, J.R. (Eds). Rev. Min. 30, $67-121$.

Kohn et al., 1992 S.C. Kohn, R. Dupree and M.G. Mortuza, The interaction between water and aluminosilicate magmas, Chem. Geol. 96 (1992), pp. 399-409.

McMillan, 1984 P.F. McMillan, Structural studies of silicate glasses and melts: applications and limitations of Raman spectroscopy, Am. Miner. 69 (1984), pp. 622644.

McMillan and Remmele, 1986 P.F. McMillan and R.L. Remmele, Hydroxyl sites in $\mathrm{SiO}_{2}$ glass: a note on infrared and Raman spectra, Am. Miner. 71 (1986), pp. $772-$ 778.

Michel and Villemant, 2003 A. Michel and B. Villemant, Determination of halogens ( $F$, $\mathrm{Cl}, \mathrm{Br}, \mathrm{I})$, sulfur and water in seventeen geological reference materials, Geost. News 27 (2003), pp. 163-171.

Mysen et al., 1980 B.O. Mysen, D. Virgo, W.J. Harrison and C.M. Scarfe, Solubility mechanisms of $\mathrm{H} 2 \mathrm{O}$ in silicate melts at high pressures and temperatures: A Raman spectroscopic study, Am. Miner. 65 (1980), pp. 900-914.

Mysen and Virgo, 1986a B.O. Mysen and D. Virgo, Volatiles in silicate melts at high pressure and temperature. 2. Water in melts along the join $\mathrm{NaAlO}_{2}-\mathrm{SiO}_{2}$ and a comparison of solubility mechanisms of water and fluorine, Chem. Geol. 57 (1986), pp. 333-358. 
Mysen and Virgo, 1986b B.O. Mysen and D. Virgo, Volatiles in silicate melts at high pressure and temperature. 1. Interaction between $\mathrm{OH}$ groups and $\mathrm{Si}^{4+}, \mathrm{Al}^{3+}, \mathrm{Ca}^{2+}$, $\mathrm{Na}^{+}$and $\mathrm{H}^{+}$, Chem. Geol. 57 (1986), pp. 303-331.

Mysen, 1988 B.O. Mysen, Structure and properties of silicate melts, Elsevier, Amsterdam (1988).

Mysen, 1990 B.O. Mysen, Interaction between water and melt in the system $\mathrm{CaAl}_{2} \mathrm{O}_{4}-\mathrm{SiO}_{2}-\mathrm{H}_{2} \mathrm{O}$, Chem. Geol. 88 (1990), pp. 223-243.

Mysen et al., 1997 B.O. Mysen, F. Holtz, M. Pichavant, J.-M. Beny and J.-M. Montel, Solution mechanisms of phosphorous in quenched hydrous and anhydrous granitic glass as a function of peraluminosity, Geochim. Cosmochim. Acta 61 (1997), pp. 3913-3926.

Neuville and Mysen, 1996 D.R. Neuville and B.O. Mysen, Role of aluminium in the silicate network: in situ, high-temperature study of glasses and melts on the join $\mathrm{SiO}_{2}$ $\mathrm{NaAlO}_{2}$, Geochim. Cosmochim. Acta 60 (1996), pp. 1727-1737.

Newman et al., 1986 S. Newman, E.M. Stolper and S. Epstein, Measurement of water in rhyolitic glasses: calibration of an infrared spectroscopic technique, Am. Miner. 71 (1986), pp. 1527-1541.

Newman et al., 1988 S. Newman, S. Epstein and E. Stolper, Water, carbon dioxide, and hydrogen isotopes in glasses from the ca. 1340 A.D. eruption of the mono craters, California: constraints on degassing phenomena and initial volatile content, $J$. Volcanol. Geotherm. Res. 35 (1988), pp. 75-96.

Nowak and Behrens, $1995 \mathrm{M}$. Nowak and H. Behrens, The speciation of water in haplogranitic glasses and melts determined by in sity near-infrared spectroscopy, Geochim. Cosmochim. Acta 59 (1995), pp. 3445-3450.

Nowak and Behrens, $2001 \mathrm{M}$. Nowak and $\mathrm{H}$. Behrens, Water in rhyolitic magmas: getting a grip on a slippery problem, Earth Planet. Sci. Lett. 184 (2001), pp. 515-522.

Ohlhorst et al., 2001 S. Ohlhorst, H. Behrens and F. Holtz, Compositional dependence of molar absorptivities of near-infrared $\mathrm{OH}$ - and $\mathrm{H}_{2} \mathrm{O}$ bands in rhyolitic to basaltic glasses, Chem. Geol. 174 (2001), pp. 5-20.

Pandya et al., 1992 N. Pandya, D.W. Muenow and K.S. Shiv, The effect of bulk composition on the speciation of water in submarine volcanic glasses, Geochim. Cosmochim. Acta 56 (1992), pp. 1875-1883.

Pasteris et al., 1996 Pasteris, J.D., Wopenka, B., Wang, A., Harris, T.N., 1996. Relative timing of fluid and anhydrite saturation: another consideration in the sulfur budget of the Mount Pinatubo eruption. In: Newhall, C.G., Punongbayan, R.S. (Eds). Fire and Mud: Eruptions and Lahars of Mount Pinatubo, Philippines. University of Washington Press, Seattle, Washington, pp. 687-731. 
Pichavant et al., 1992 M. Pichavant, F. Holtz and P.F. McMillan, Phase relations and compositional dependence of $\mathrm{H}_{2} \mathrm{O}$ solubility in quartz-feldspar melts, Chem. Geol. 96 (1992), pp. 303-319.

Rossotti and Carrasco-Nunez, 2004 A. Rossotti and G. Carrasco-Nunez, Stratigraphy of the 8.5-9 ka BP Citlaltepetl pumice fallout sequence, Rev. Mex. Cienc. Geol. 21 (2004), pp. 353-370.

Scaillet et al., 1995 B. Scaillet, M. Pichavant and J. Roux, Experimental crystallization of leucogranite magmas, J. Petr. 36 (1995), pp. 663-705.

Scaillet and Evans, 1999 B. Scaillet and B.W. Evans, The 15 June 1991 eruption of Mount Pinatubo. I. Phase equilibria and pre-eruption P-T- $\mathrm{fO}_{2}-\mathrm{fH}_{2} \mathrm{O}$ conditions of the dacite magma, J. Petr. 40 (1999), pp. 381-411.

Scaillet and Mcdonald, 2001 B. Scaillet and R. Mcdonald, Phase relations of peralkaline silicic magmas and petrogenetic implications, J. Petr. 42 (2001), pp. 825845.

Scaillet and Pichavant, 2004 B. Scaillet and M. Pichavant, Crystallization conditions of Vesuvius phonolites, Geophys. Res. (2004), p. 03764 (Abstract 6).

Schmidt et al., 2001 B.C. Schmidt, H. Behrens, T. Riemer, R. Kappes and R. Dupree, Quantitative determination of water speciation in aluminosilicate glasses: a comparative NMR and IR spectroscopic study, Chem. Geol. 174 (2001), pp. 195208.

Sharma et al., 1981 S.K. Sharma, J.F. Mammine and M.F. Nicol, Raman investigation of ring configuration in vitreous silica, Nature 292 (1981), pp. 140-141.

Sharma et al., 1997 S.K. Sharma, T.F. Cooney, Z. Wang and S. van der Laan, Raman band assignments of silicate and germanate glasses using high-pressure and high-temperature spectral data, J. Raman Spectrosc. 28 (1997), pp. 697-709.

Sharygin, 1993 V.V. Sharygin, Melt evolution during crystallisation of haüyne phonolites of east Eifel (W. Germany), Russian Geol. Geophys. 34 (1993), pp. 8495.

Slejko et al., 2004 F.F. Slejko, R. Petrini, G. Orsi, M. Piochi and C. Forte, Water speciation and Sr isotopic exchange during water-melt interaction: A combined NMRTIMS study on the Cretaio Tephra (Ischia Island, south Italy), J. Volcanol. Geotherm. Res. 133 (2004), pp. 311-320.

Sowerby and Keppler, 1999 J.R. Sowerby and H. Keppler, Water speciation in rhyolitic melt determined by in-situ infrared spectroscopy, Am. Miner. 84 (1999), pp. 1843-1849.

Stolper, 1982 E. Stolper, Water in silicate glasses: an infrared spectroscopic study, Contrib. Miner. Petrol. 81 (1982), pp. 1-17. 
Silver et al., 1990 L.A. Silver, P.D. Ihinger and E. Stolper, The influence of bulk composition on the speciation of water in silicate glasses, Contrib. Miner. Petrol. 104 (1990), pp. 142-162

Thomas, $2000 \mathrm{R}$. Thomas, Determination of water contents of granite melt inclusions by confocal laser Raman microprobe spectroscopy, Am. Miner. 85 (2000), pp. 868872.

Thomas, 2002 Thomas, R., 2002. Determination of water contents in melt inclusions by laser Raman spectroscopy. In: B. De Vivo, B., Bodnar, R.J. (Eds.), Proceedings, September 26-30th, Workshop-Short Course on Volcanic Systems, Geochemical and Geophysical Monitoring-Melt inclusions: methods, applications and problems. Seiano di Vico Equense, Italy, 211-216.

Uchino et al., 1991 T. Uchino, T. Sakka and M. Iwasaki, Interpretation of hydrated states of sodium silicate glasses by Infrared and Raman analysis, J. Am. Ceram. Soc. 74 (1991), pp. 306-313

Villemant et al., 2003 Villemant, B., Boudon, G., Nougrigat, S., Poteaux, S., Michel, A., 2003. $\mathrm{H}_{2} \mathrm{O}$ and halogen in volcanic clasts: Tracers of degassing processes during plinian and dome-forming eruptions. In: Oppenheimer, C., Pyle, D.M., Barclay, J. (Eds.), Geol. Soc. Lond., Special Publication, vol. 213, pp. 63-79.

Wallace et al., 2003 P.J. Wallace, J. Dufek, A.T. Anderson and Y. Zhang, Cooling rates of Plinian-fall and pyroclastic-flow deposits in the Bishop Tuff: Inferences from water speciation in quartz-hosted glass inclusions, Bull. Volcanol. 65 (2003), pp. 105-123.

Whittington et al., 2001 A. Whittington, P. Richet, Y. Linard and F. Holtz, The viscosity of hydrous phonolites and trachytes, Chem. Geol. 174 (2001), pp. 209-223.

Wopenka et al., 1990 B. Wopenka, J.D. Pasteris and J.J. Freeman, Analysis of individual fluid inclusions by Fourier transform infrared and Raman microspectroscopy, Geochim. Cosmochim. Acta 54 (1990), pp. 519-533.

Wu, 1980 C.K. Wu, Nature of incorporated water in hydrated silicate glasses, J. Am. Ceram. Soc. 63 (1980), pp. 453-457.

Xue and Kanzaki, 2004 X. Xue and M. Kanzaki, Dissolution mechanisms of water in depolymerized silicate melts: constraints from $1 \mathrm{H}$ and 29Si NMR spectroscopy and ab initio calculations, Geochim. Cosmochim. Acta 68 (2004), pp. 5027-5057.

Zhang et al., 1995 Y. Zhang, E.M. Stolper and P.D. Ihinger, Kinetics of the reaction $\mathrm{H}_{2} \mathrm{O}+\mathrm{O}=2 \mathrm{OH}$ in rhyolitic and albitic glasses: preliminary results, Am. Miner. 80 (1995), pp. 593-612.

Zotov and Keppler, $1998 \mathrm{~N}$. Zotov and H. Keppler, The influence of water on the structure of hydrous sodium tetrasilicate glasses, Am. Miner. 83 (1998), pp. 823-834. 
Zotov, 2003 N. Zotov, Structure of natural volcanic glasses: diffraction versus spectroscopic perspective, J. Non-Cryst. Solids 323 (2003), pp. 1-6. 